\title{
Review
}

\section{The Double Face of Metals: The Intriguing Case of Chromium}

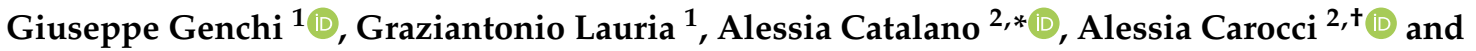 \\ Maria Stefania Sinicropi ${ }^{1,+}$ (iD \\ 1 Dipartimento di Farmacia e Scienze della Salute e della Nutrizione, Università della Calabria, \\ 87036 Cosenza, Italy; giuseppe.genchi@unical.it (G.G.); glauria@unical.it (G.L.); s.sinicropi@unical.it (M.S.S.) \\ 2 Dipartimento di Farmacia-Scienze del Farmaco, Università degli Studi di Bari “A. Moro”, 70125 Bari, Italy; \\ alessia.carocci@uniba.it \\ * Correspondence: alessia.catalano@uniba.it; Tel.: +39-0805442731 \\ + These Authors equally contributed to this work.
}

check for updates

Citation: Genchi, G.; Lauria, G.; Catalano, A.; Carocci, A.; Sinicropi, M.S. The Double Face of Metals: The Intriguing Case of Chromium. Appl. Sci. 2021, 11, 638. https://doi.org/ 10.3390/app11020638

Received: 10 December 2020 Accepted: 8 January 2021 Published: 11 January 2021

Publisher's Note: MDPI stays neutral with regard to jurisdictional clai$\mathrm{ms}$ in published maps and institutional affiliations.

Copyright: $\odot 2021$ by the authors. Licensee MDPI, Basel, Switzerland. This article is an open access article distributed under the terms and conditions of the Creative Commons Attribution (CC BY) license (https:// creativecommons.org/licenses/by/ $4.0 /)$.

\begin{abstract}
Chromium (Cr) is a common element in the Earth's crust. It may exist in different oxidation states, $\mathrm{Cr}(0), \mathrm{Cr}(\mathrm{III})$ and $\mathrm{Cr}(\mathrm{VI})$, with $\mathrm{Cr}(\mathrm{III})$ and $\mathrm{Cr}(\mathrm{VI})$ being relatively stable and largely predominant. Chromium's peculiarity is that its behavior relies on its valence state. $\mathrm{Cr}$ (III) is a trace element in humans and plays a major role in glucose and fat metabolism. The beneficial effects of $\mathrm{Cr}(\mathrm{III})$ in obesity and types 2 diabetes are known. It has been long considered an essential element, but now it has been reclassified as a nutritional supplement. On the other hand, $\mathrm{Cr}(\mathrm{VI})$ is a human carcinogen and exposure to it occurs both in occupational and environmental contexts. It induces also epigenetic effects on DNA, histone tails and microRNA; its toxicity seems to be related to its higher mobility in soil and swifter penetration through cell membranes than $\mathrm{Cr}(\mathrm{III})$. The microorganisms Acinetobacter sp. Cr1 and Pseudomonas sp. Cr13 have been suggested as a promising agent for bioremediation of $\mathrm{Cr}(\mathrm{VI})$. This review intends to underline the important role of $\mathrm{Cr}(\mathrm{III})$ for human health and the dangerousness of $\mathrm{Cr}(\mathrm{VI})$ as a toxic element. The dual and opposing roles of this metal make it particularly interesting. An overview of the recent literature is reported in support.
\end{abstract}

Keywords: chromium; essential nutrient; toxic element; epigenetics; remediation

\section{Introduction}

Heavy metals are pollutants present in the air and in the soil from natural and anthropogenic sources. Among heavy metals, chromium represents a fascinating case. In its prevalent oxidation states, III and VI, it has completely different characteristics in terms of toxicity and essentiality in human health, and behavior in the soil. $\mathrm{Cr}$ (III) derives from anthropogenic sources and is an essential nutrient for humans. It has been defined a pharmacologically active element considering its important role in carbohydrate and lipid metabolism and in the maintenance of the structural integrity of nucleic acids [1]. $\mathrm{Cr}$ (III) is a constituent of glucose tolerance factor (GTF): this factor is synthesized in vivo from absorbed dietary chromium and it modulates the rate of removal of glucose from blood with an insulin boosting mechanism. Cr(III) improves insulin activity, as it binds to insulin and potentiates its action by about three-fold. Therefore, chromium deficiencies can lead to pathologies associated with carbohydrates and weight loss [2,3].

Recently, the potential utilization of chromium to fight thermal stress in animals has been reported. Heat stress (HS) may influence nutrient digestion, carcass quality and the immune system. Homeorhetic adaptations, generally caused by increased circulation of insulin, may be also altered. Cr(III) prevents HS-induced lipid peroxidation, increases nutrient metabolism and cortisol hormone activity, stimulates the action of insulin in responsive tissues and thus it may act in fighting the side effects of heat stress in animals $[4,5]$. The required daily dose of $\mathrm{Cr}$ (III) is 10-40 $\mu \mathrm{g}$ for children up to six months, and 25-35 $\mu \mathrm{g}$ for other ages [6]. Insufficient dietary $\mathrm{Cr}$ (III) also induces symptoms equal to diabetes and cardiovascular 
diseases. The deficiency of this metal can cause blood sugar spikes, elevated cholesterol levels and blood pressure. It may also have other consequences, such as lower resistance to infections, atherosclerosis, hormonal imbalance, nervous disorders, fatigue, etc., [7,8].

$\mathrm{Cr}$ (III) occurs in several foods and supplementation products. It is largely contained in baker's yeast, red meat, liver, whole grains, red beets; however, it is hardly assimilated (only $3 \%$ is retained by body). The most common supplementation products include chromiumpicolinate (CrPic), chromium-histidinate (CrHis), chromium-dinicocysteinate (CRDC), and niacin-bound chromium (NBC) [9]. Several studies have been developed to evaluate the safety and efficacy of these supplements as insulin-sensitizing agents useful for prevention and treatment of type 2 diabetes (T2DM) and obesity [10-14]. However, excessive levels of chromium can determine pathological states. In fact, even if $\mathrm{Cr}$ (III) compounds are not able to cross cell membranes, they may accumulate around cells causing alterations in cell functions and damaging the cell-membranes. In fact, long time exposure to $\mathrm{Cr}(\mathrm{III})$ may lead to skin allergies and cancer [15]. Levina et al. (2008) reported also that the accumulation of $\mathrm{Cr}$ (III)-based dietary supplements, such as CrPic could induce genotoxic effects [16]. In the supplements $\mathrm{Cr}$ (III) may undergo a series of chemical transformations in biological media.

Products deriving from partial hydrolysis of nutritional supplements containing $\mathrm{Cr}$ (III) may give reactive species while generation of highly reactive $\mathrm{Cr}(\mathrm{VI} / \mathrm{V} / \mathrm{IV})$ species and organic radicals may derive from reactions of $\mathrm{Cr}(\mathrm{III})$ with biological oxidants. However, it must be considered that $\mathrm{Cr}(\mathrm{III})$ compounds possess low bioavailability [17]. Eastmond et al. (2008) reported that the genotoxic effects in vivo are uncommon but they can occur for elevated physiological intake levels of $\mathrm{Cr}$ (III) supplements [18]. While $\mathrm{Cr}$ (III) is an essential trace element, found in nature in rocks and soil, readily absorbed by plants, hexavalent chromium is mainly an industrial contaminant and is also produced from anthropogenic activities. $\mathrm{Cr}(\mathrm{VI})$ compounds present several applications and are vastly used as pigments for textile tints, paints, inks, plastics, corrosion preventing agents, leather tanning agents and wood preservatives [19]. Hexavalent chromium is mainly used in tanneries or industries dealing with metalworking, stainless steel welding, chromate production and the manufacture of chromium pigments [20]. The release of $\mathrm{Cr}(\mathrm{VI})$ into the air is mainly due to these industrial processes. Chromium in the environment may be derived by inhalation of contaminated air and water $[9,21]$. High chromium concentration mainly in water bodies may derive from waste from the ferrochrome industry, such as slag, dust and processed water [22]. Chromium discharge in European Union (EU) waters is subjected to nationwide recommendations, which may vary depending on the type of industry and receiving water body [23]. Cr(VI) is classified by IARC (International Agency for Research on Cancer) as a human carcinogen (class I) [24]. The respiratory tract is the major target for the toxic and carcinogenic action of hexavalent chromium. Acute and chronic occupational exposure mainly occurs by inhalation. This review intends to be an overview of recent research on the double face of chromium as an essential nutrient and as a toxic metal.

\section{Chemical Form and Properties of Chromium}

Chromium is the 24th element in the periodic table and its symbol is $\mathrm{Cr}$. It was discovered in 1798 by L. N. Vauquelin. It belongs to transition metals and its average atomic weight is $52 \mathrm{~g} / \mathrm{mol}$. Its physicochemical properties are summarized in Table 1. Chromium is the first element of the sixth group; it is a steely-grey, shiny, hard and brittle metal. It is the twenty-first most abundant element in the Earth's crust [25]. While it does not react with water, it may react with acids. Chromium may theoretically occur in oxidation states between -2 and +6 , but the most common oxidation states are +3 and $+6[\mathrm{Cr}(\mathrm{III})$ and $\mathrm{Cr}(\mathrm{VI})] \cdot \mathrm{Cr}^{2+}$ is unstable and oxidizes to $\mathrm{Cr}^{3+}$ when in contact with air. Elemental chromium $(\mathrm{Cr}(0))$ is not present in nature in the Earth's crust and is physiologically inert. $\mathrm{Cr}(0)$ in its inert metallic form and at a concentration of about $11 \%$ is found almost exclusively as a constituent of iron alloys as stainless steel. The addition of $8 \%$ nickel to this alloy increases corrosion resistance [26]. Chromium owes its name to its many-colored compounds colors such as black, green, blue, 
violet, yellow, orange and red; thus, it has been used in paints and pigments. Common uses of chromium are summarized in Table 2. Chromium is both an essential trace element $\left(\mathrm{as} \mathrm{Cr}^{3+}\right)$ ion and an environmental toxicant $\left(\mathrm{as}^{6}{ }^{6+}\right)$. The latter is considered a heavy metal. However, long time exposure to $\mathrm{Cr}(\mathrm{III})$ may lead to skin allergy and cancer [15,27]. In aqueous solutions, $\mathrm{Cr}(\mathrm{VI})$ may exist as chromate ion $\left(\mathrm{CrO}_{4}{ }^{2-}\right)$ or as dichromate or bichromate ion $\left(\mathrm{Cr}_{2} \mathrm{O}_{7}{ }^{2-}\right)$. $\mathrm{Cr}^{3+}$ in aqueous solutions is green, $\mathrm{CrO}_{4}{ }^{2-}$ confers a yellow color to water, while $\mathrm{Cr}_{2} \mathrm{O}_{7}{ }^{2-}$ is orange. $\mathrm{Cr}(\mathrm{VI})$ solutions are vigorous oxidizing agents in acidic conditions. Chromic acid $\left(\mathrm{H}_{2} \mathrm{CrO}_{4}\right)$ is utilized for cleaning glassware in chemistry laboratories by oxidizing organic residues. In anoxic conditions, a chromium trivalent form prevails, while the hexavalent form prevails in aerobic conditions. Chromate ions, especially potassium chromate $\left(\mathrm{K}_{2} \mathrm{CrO}_{4}\right)$, are used as indicators in the titration of chloride ions with silver nitrate in the Mohr method [28], while the potassium bichromate $\left(\mathrm{K}_{2} \mathrm{Cr}_{2} \mathrm{O}_{7}\right)$ titrimetric method is used to determine chemical oxygen demand (COD), that is the amount of oxygen needed to destroy all organic matter contained in water [29].

Table 1. Physical and chemical properties of chromium.

\begin{tabular}{cc}
\hline Atomic number & 24 \\
\hline Atomic weight & $51.9961 \mathrm{u}$ \\
\hline Atomic radius & $130 \mathrm{pm}$ \\
\hline Electronic configuration & {$[\mathrm{Ar}] 4 \mathrm{~s}^{1} 3 \mathrm{~d}^{5}$} \\
\hline Melting point & $1907^{\circ} \mathrm{C}$ \\
\hline Boiling point & $2672{ }^{\circ} \mathrm{C}$ \\
\hline Density at $20^{\circ} \mathrm{C}$ & $7.18 \mathrm{~g} / \mathrm{cm}^{3}$ \\
\hline Heat of fusion & $21 \mathrm{KJ} / \mathrm{mol}$ \\
\hline Heat of vaporization & $342 \mathrm{KJ} / \mathrm{mol}$ \\
\hline Pauling electronegativity number & 1.66 \\
\hline First ionization energy & $652.4 \mathrm{KJ} / \mathrm{mol}$ \\
\hline Second ionization energy & $1590.6 \mathrm{KJ} / \mathrm{mol}$ \\
\hline Third ionization energy & $2987 \mathrm{KJ} / \mathrm{mol}$ \\
\hline
\end{tabular}

Table 2. Uses of chromium.

\begin{tabular}{|c|c|}
\hline Form & Uses \\
\hline \multirow{3}{*}{$\mathrm{Cr}(\mathrm{O})$} & Stainless steel production \\
\hline & Alloy production \\
\hline & Metal and alloy manufacturing \\
\hline \multirow{5}{*}{$\mathrm{Cr}(\mathrm{III})$} & Metal and alloy manufacturing \\
\hline & Brick lining \\
\hline & Chrome plating and welding \\
\hline & Leather tanning \\
\hline & Textiles \\
\hline \multirow{6}{*}{$\mathrm{Cr}(\mathrm{VI})$} & Chrome plating and welding \\
\hline & Copying machine toner \\
\hline & Chrome plating \\
\hline & Leather tanning \\
\hline & Textiles \\
\hline & Wood preservatives \\
\hline
\end{tabular}


$\mathrm{Cr}(\mathrm{III})$ is a micronutrient essential in humans for the metabolism of carbohydrates, lipids and proteins. It is considered the main trace mineral involved in the amelioration and prevention of hyperglycemia and hyperlipidemia in T2DM, as a component of GTF. Administration of $\mathrm{Cr}$ (III) orally may markedly alleviate the diabetic-like symptoms [30]. $\mathrm{Cr}(\mathrm{III})$ enhances insulin signaling in different tissues [31]. Additionally, trivalent chromium inhibits hepatic enzyme 3-hydroxy-3-methylglutaryl coenzyme A (HMG-CoA) reductase and interferes with cholesterol metabolism [32]. $\mathrm{Cr}(\mathrm{III})$ is also involved in the reduction of plasma cholesterol and triglycerides and in the preservation of normal glucose levels in the blood and in the inhibition of oxidative stress [10]. However, recent studies demonstrated that $\mathrm{Cr}$ (III) does not induce human low density lipoprotein (LDL) oxidation at $\mathrm{pH} 4.5$ or 7.4 under the experimental conditions used, thus suggesting caution when evaluating LDL oxidation and lipid peroxidation induced by trivalent chromium [33]. $\mathrm{Cr}(\mathrm{III})$ present in the soil may undergo natural oxidation processes being converted to $\mathrm{Cr}(\mathrm{VI})$; these oxidation processes may also be influenced by manganese levels. High levels of this metal in the soil as well as the high values of $\mathrm{pH}$ in the soil may influence oxidation processes [34]. Trivalent chromium may be easily taken up by plants from the soil; in this way, $\mathrm{Cr}$ (III) can enter the food chain of the diet of living beings. $\mathrm{Cr}(\mathrm{III})$, as well as being in the daily diet, is present in many nutritional supplements in the form of CrPic, CrHis, CRDC and NBC. Among these nutritional supplements, $\mathrm{CrPic}$ is the most easily absorbed $[35,36]$. Some in vitro studies evidenced that $\mathrm{Cr}$ (III) can react with DNA thus causing DNA damage in cell cultures, but in normal conditions, the limited entry of $\mathrm{Cr}$ (III) into cells in vivo limits its genotoxic effects in biological systems. Therefore, the genotoxic effects are rare in animals and humans exposed to nutritional doses or moderate supplemental doses of $\mathrm{Cr}$ (III), but they are more likely for modestly elevated physiological intake levels [18].

$\mathrm{Cr}(\mathrm{VI})$ is seldom found in nature and it mainly derives from industrial and anthropogenic activities. It is used in industry in stainless steel, chrome plating, welding, leather tanning and as corrosion inhibitor. $\mathrm{Cr}(\mathrm{VI})$ is toxic and carcinogenic and is a respiratory irritant which determines phospholipid peroxidation, DNA damage, chromosomal aberration, epigenomic instability and cell death. $\mathrm{Cr}(\mathrm{VI})$, which structurally resembles phosphate and sulfate anions, may easily cross cell membranes via nonspecific anionic transfer systems, while $\mathrm{Cr}$ (III) cannot enter cells [37]. In the environment $\mathrm{Cr}(\mathrm{VI})$ may be found as chromate oxyanion $\left(\mathrm{CrO}_{4}{ }^{2}\right)$, which is structurally similar to sulphate and phosphate anions; for this reason, the anion transport protein, called Band 3, transports sulphate, phosphate and chromate ions, as well $[38,39]$ (Figure 1). After food or water ingestion, $\mathrm{Cr}(\mathrm{VI})$ may be reduced to $\mathrm{Cr}$ (III) by the action of saliva and highly acidic gastric juice and then taken by intestinal bacteria [40]. Reduction of $\mathrm{Cr}(\mathrm{VI})$ to $\mathrm{Cr}(\mathrm{III})$ into cells generates $\mathrm{Cr}(\mathrm{V})$ and $\mathrm{Cr}(\mathrm{IV})$ intermediate ions: this process depends on the reducing agent and their concentration. Cysteine acts as a one-electron reducer forming $\mathrm{Cr}(\mathrm{V})$; the reducing reaction in the presence of GSH proceeds through either one- or two-electron transfer forming $\mathrm{Cr}(\mathrm{V})$ and $\mathrm{Cr}(\mathrm{IV})$, while ascorbate is a two-electron donor, giving $\mathrm{Cr}(\mathrm{IV})[37,41]$ (Figure 1). 


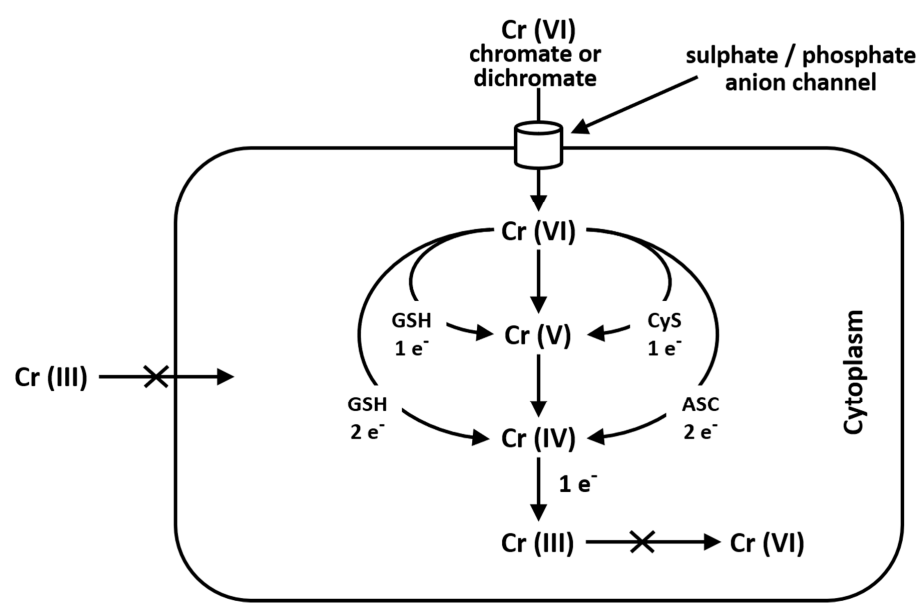

Figure 1. Pathway of chromium metabolism in the cell. $\mathrm{Cr}(\mathrm{III})$ is unable to cross the cellular membrane, while $\mathrm{Cr}(\mathrm{VI})$, being structurally similar to phosphate and sulfate, crosses the cellular membrane via a nonspecific anion channel. In the cell, $\mathrm{Cr}(\mathrm{VI})$ undergoes metabolic reduction to $\mathrm{Cr}(\mathrm{III})$ in the presence of Asc, GSH and Cys [38,41].

Once inside cells, $\mathrm{Cr}(\mathrm{VI})$ undergoes metabolic reductions and is converted to $\mathrm{Cr}(\mathrm{III})$ in the presence of ascorbate, reduced glutathione (GSH), cysteine (Cys), cytochrome P450 reductase, glutathione reductase, aldehyde oxidase, catalase, glutathione peroxidase, superoxide dismutase, glutathione S-transferase and thioredoxin reductase. Moreover, the mitochondrial electron transport chain (complex I, also called NADH: ubiquinone oxide reductase; complex III, also called ubiquinone: cytochrome C oxide reductase) is a $\mathrm{Cr}(\mathrm{VI})$ potent reducing agent [42,43]. Simultaneously with conversion of $\mathrm{Cr}(\mathrm{VI})$ to $\mathrm{Cr}(\mathrm{III})$, Fenton reaction produces reactive oxygen species (ROS), like hydrogen peroxide $\left(\mathrm{H}_{2} \mathrm{O}_{2}\right)$, hydroxyl radicals $\left({ }^{\bullet} \mathrm{OH}\right)$ and superoxide anion radicals $\left(\mathrm{O}_{2}{ }^{\bullet-}\right)$ (Figure 2). Several authors demonstrated that chromium is capable of altering the epigenetic profile of cells in DNA methylation, histone and microRNA post-translational modifications [44-47].

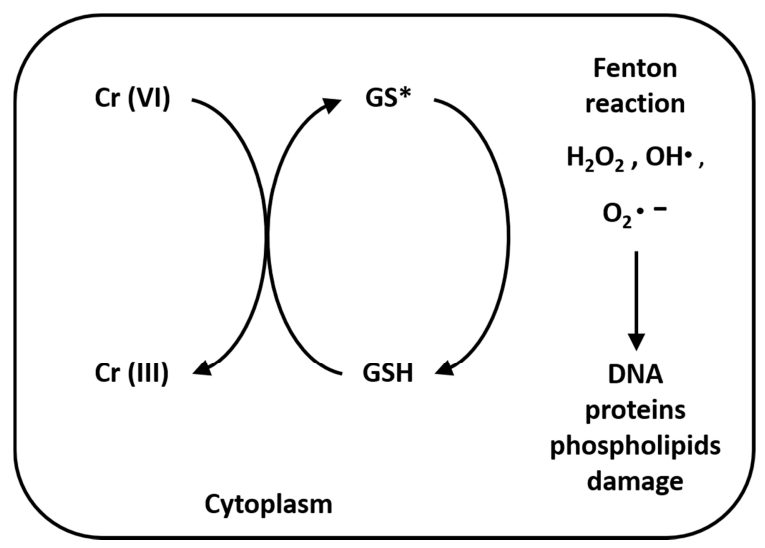

Figure 2. Reduction reaction of $\mathrm{Cr}(\mathrm{VI})$ to $\mathrm{Cr}(\mathrm{III})$ and Fenton reaction. The reaction process of $\mathrm{Cr}(\mathrm{VI})$ to $\mathrm{Cr}(\mathrm{III})$, especially in the presence of GSH, produces hydrogen peroxide $\left(\mathrm{H}_{2} \mathrm{O}_{2}\right)$, hydroxyl radicals $\left({ }^{\bullet} \mathrm{OH}\right)$ and superoxide anion radicals $\left(\mathrm{O}_{2}{ }^{\bullet}\right)$, due to Fenton reaction. These ions are very unstable, causing lipid peroxidation, DNA and protein damage [37].

\section{Bioavailability, Absorption and Excretion of $\mathrm{Cr}(\mathrm{III})$ and $\mathrm{Cr}(\mathrm{VI})$}

Brewer's yeast, sea food, oysters, liver, meat, cheese, fruits, green beans, spinach and broccoli are dietary sources rich in $\mathrm{Cr}$ (III) (Table 3). Chromium content in food is influenced by its presence in the soil in which the plants and vegetables grow and by feedstuffs fed to animals and contamination during processing or cooking methods in $\mathrm{Cr}$-containing stainless-steel equipment $[48,49]$. The estimated safe and adequate daily dietary intake for $\mathrm{Cr}(\mathrm{III})$, established by the National Research Council, is 50-200 $\mu \mathrm{g}$ /day corresponding 
to $0.71-2.9 \mu \mathrm{g} / \mathrm{kg} /$ day for a $70 \mathrm{~kg}$ adult [10]. In 2001, the Food and Nutrition Board at the Institute of Medicine of the National Academies of Sciences (US) specified the daily chromium intake at a value of $25 \mu \mathrm{g}$ and $35 \mu \mathrm{g}$ for women and men, respectively [50]. Maximum intake levels are up to $250 \mu \mathrm{g} /$ day for supplemental intake as suggested by the World Health Organization (WHO); these are in the same order of magnitude as the exposure resulting from normal dietary intake [51]. $\mathrm{Cr}$ (III) is a natural constituent of the diet and may be found in a multiplicity of foods and supplements, whereas $\mathrm{Cr}(\mathrm{VI})$ mostly derives from industrial processes and may be found in drinking water as a result of anthropogenic contamination $[52,53]$.

Table 3. Food sources of chromium.

\begin{tabular}{cc}
\hline Food & Cr $(\mu \mathbf{g} / \mathbf{k g})$ \\
\hline Mussels & 128 \\
Brewer's yeast & 112 \\
Brazil nuts & 100 \\
Oysters & 57 \\
Wholemeal bread & 42 \\
Rye bread & 30 \\
Dried dates & 29 \\
Pears & 27 \\
Shrimps & 26 \\
Broccoli & 25 \\
Whole wheat flour & 21 \\
Tomatoes & 20 \\
Whole meal barley & 13 \\
Hazelnuts & 12 \\
Whole corn & 9 \\
\hline
\end{tabular}

$\mathrm{Cr}(\mathrm{III})$ is absorbed in the gut through the unsaturated passive transport. The absorption intake depends on the chromium quantity in the food and the chemical form of this element (i.e., chloride, picolinate, nicotinate, etc.). The absorption of chromium in human beings is much higher in the form of yeast chromium (5-10\%) than CrPic (2.8\%) or $\mathrm{CrCl}_{3}(0.1-0.4 \%)$ (European Commission 2003) [54]. Organic chromium (i.e., picolinate, nicotinate, methionine, histidinate) is better absorbed than inorganic [55]. In 2007, Zha and co-authors reported that the highest correlation dose/accumulation in the tissues occurred when chromium nanoparticles were used (average size $40-50 \mathrm{~nm}$ ) [56]. However, other factors are related to the absorption of this element: ascorbic acid, aspirin, oxalic acid, simple sugar, nicotinic acid and some amino acids may enhance the absorption of chromium, whereas calcium, magnesium, zinc, titanium, iron and phosphate reduce the level of absorption [57]. A chromium deficiency has been noted in athletes after strenuous exercise, pregnant women, and the elderly because of their difficulty in absorbing inorganic chromium in an adequate amount to convert into the active form [58]. Chromium absorbed by passive diffusion represents only about $1 \%$ [59].

After being absorbed from the intestine, $\mathrm{Cr}(\mathrm{III})$ is released into the bloodstream, and its transportation is mediated by transferrin, a $\beta$-globulin, followed by receptor-mediated endocytosis, and then transferred to cells of various tissues, first of all, liver and kidneys [60]. Transferrin is a serum protein, involved in iron metabolism and responsible for transporting $\mathrm{Fe}(\mathrm{III})$ in the bloodstream [61]. This protein is also involved in the transport of $\mathrm{Cr}$ (III) because of its similarity to the ferric ion both in size and charge [62]. Transferrin holds two binding sites for iron with different affinities depending on $\mathrm{pH}$. Chromium has been shown to bind only to one of these sites. The antagonism between chromium/iron might cause an enhancement in hematological parameters (hemoglobin, hematocrit, erythrocytes and mean erythrocyte volume), described in chromium deficiency [63]. Chromium passes from cells into blood circulation and is eliminated in urine $(80 \%)$, while the remaining $20 \%$ is excreted via feces and sweat [64]. In humans, pregnancy and lactation, exhaustive 
physical exercise and consumption of large amounts of sugar with the diet lead to increase chromium excretion in the urine. $\mathrm{Cr}(\mathrm{VI})$ that is not reduced by gastric fluid may pass into the small intestine [65]. $\mathrm{Cr}(\mathrm{VI})$ that has entered the small intestine can be reduced outside cells, excreted in feces, or enter villus enterocytes by anion transporters. Recently, chromium level imbalances have been observed in alcohol-use disorders [66].

\section{The Role of Chromium and Its Mechanism of Action in the Body}

The first literature study about a physiological role of chromium in the body appeared in 1959 by Schwarz and Mertz [67]. The authors isolated from pig kidney and Brewer's yeast the GTF, a component capable of rebalancing impaired glucose tolerance in rats; the active component of this factor was discovered to be chromium. About forty years later chromium was considered an element necessary in small quantities for proper functioning of human beings [68]; anyway nowadays, chromium is classified as a nutritional supplementation factor.

In recent years, several studies on the influence of chromium on cholesterol level and lipid profile have been published. Dietary supplementation with high amounts of chromium has been demonstrated that, while decreasing the serum level of total cholesterol, LDL-cholesterol (LDL-c), nonesterified fatty acids and triglycerides, led to an enhanced concentration of high density lipoprotein (HDL)-cholesterol and $\beta$-oxidation process [69]. The oral administration in mice of chromium nitrate cancels and counteracts the anticarcinogenic mechanism of selenium effects in the development and growth of mouse mammary tumors caused by mouse mammary tumor virus (MMTV) [70]. Despite the numerous studies published so far, it is still unclear how chromium ions can operate in the metabolism of lipids and carbohydrates. Probably, the active form of $\mathrm{Cr}$ (III) is transported through the body via chromodulin, a low-molecular-weight chromium-binding substance (LMWCr), that is thought to influence lipid and carbohydrate metabolism. LMWCr is a small 1500 Da oligopeptide consisting of ten amino acids (2 Gly, 2 Cys, 2 Asp, 4 Glu) [71]. LMWCr has been demonstrated to be within the cytoplasm and nucleus of the cell in an inactive form (i.e., apochromodulin). After insulin binding and activation of the transferrin receptor, there is an internalization in the cell of transferrin-chromium complex. Chromodulin binds four $\mathrm{Cr}$ (III) ions, and then is converted into holochromodulin, the biologically active form. This holopeptide may bind the insulin receptor at the level of $\beta$-subunit, activating the tyrosine kinase receptor and thus enhancing the insulin signal. All these mechanisms mediate glucose transport into the cell through the cell membrane thanks to the protein glucose transporter 4 (GLUT4) [72]. Other theories are known to justify the importance of chromium in glucose metabolism. For example, according to Pattar and collaborators (2006), the $\mathrm{Cr}$ ions act on the membrane fluidity regulating the glucose uptake by the cells [73]. The fluidity of the membrane, also considering the presence of $\mathrm{Cr}$ ions, is associated with the reduced content of cholesterol in the cellular membranes. The lower presence of cholesterol, which affects membrane fluidity, is considered to be another factor that diminishes insulin-controlled glucose intake. Furthermore, Raja et al. (2011) demonstrated that $\mathrm{Cr}$ (II) ions modify the structure of the lipid bilayer [74]. Adam et al. (2017) studied the mechanism responsible for contact dermatitis by chromium [75]. It seems that $\mathrm{Cr}(\mathrm{VI})$ penetrates through the skin and is then reduced to $\mathrm{Cr}(\mathrm{III})$, which may react with proteins to form a hapten, thus creating the complex recognized by $\mathrm{T}$ cells. Chromium activates $\mathrm{T}$ cells leading to inflammation and, lastly, symptoms [76].

\section{Chromium(III) in Diabetes and Supplements}

In the twenty-first century, the incidence of diabetes in the world population has increased dramatically. T2DM is characterized by high glycaemia, resistance to insulin, and relative deficiency of insulin. T2DM is related to different risk factors such as obesity, increased age, pancreatitis, cancer, family history, viral infections and immune diseases. Mechanisms such as oxidative stress, $\beta$-cell glucotoxicity, lipotoxicity and changes in gut microbiome compositions may influence insulin activity in T2DM [77,78]. Some dietary 
deficiencies, such as $\mathrm{Cr}$ (III) deficiency, have also been associated with diabetes: in fact, highly refined diets, that are poor in $\mathrm{Cr}(\mathrm{III})$, have been identified as a cause of diabetes incidence. T2DM is largely preventable by staying a normal weight, eating properly and exercising regularly.

Metabolic syndrome is related to a defect in insulin action and a compensatory increase in blood of this hormone [79]. Insulin resistance takes place when insulin is no longer able to metabolize glucose, thus leading to an increase of glucose and insulin levels in bloodstream. Recent studies showed that $\mathrm{Cr}$ (III) supplementation significantly decreases blood glucose concentration as well as lowers cholesterol and LDL in T2DM [80]. NBC supplementation also increases AMP protein kinase (AMPK) and protein kinase Akt phosphorylation and facilitates the GLUT4 translocation in the cell membrane [81].

Jain et al. (2012) studied the results of CRDC and CrPic supplements (400 $\mu \mathrm{g} /$ day) in type 2 diabetic human beings and found that the concentrations of intercellular adhesion molecule-1 (ICAM-1), interleukin-6 (IL-6) and interleukin-8 (IL-8) did not change if comparing what happened before and after supplementation with chromium alone or placebo. The authors also observed a significant reduction in tumor necrosis factor- (TNF-) after 3 months of CRDC supplementation compared to baseline [82]. A few years later (2016), Saiyed et al. also demonstrated that the supplementation of $400 \mu \mathrm{g} /$ daily of CRDC for a same period (3 months) decreased TNF- levels compared to placebo [83]. Abebe et al. (2010) examined the influence of $\mathrm{CrPic}$ in myocardial ischemia-reperfusion injury (IRI) [84]. CrPic was suggested as a supplement in patients with T2DM/impaired glucose tolerance with systemic hypertension, abnormal vascular function and ischemic heart disease. CrPic treatment determined an improvement of endothelium-dependent vasorelaxation and nitric oxide (NO) production. Moreover, it improved recovery of myocardium after IRI [85,86]. Cr supplementation was also demonstrated to have a positive impact in heat-stressed buffalo calves and chickens. It also enhances insulin action in insulin-sensitive tissues, such as adipose tissue and muscles thus increasing feed intake, growth rate, carcass quality, reproductive parameters and ameliorating immune functions, finally leading to an increase in farm animal productivity [5].

\section{Toxicity of Chromium(VI)}

Hexavalent chromium $(\mathrm{Cr}(\mathrm{VI}))$ toxicity relies on its strong oxidizing ability and easy absorption by the cells through nonspecific anion carrier proteins [38,39,42]. After entering cells, hexavalent chromium may be quickly converted into the trivalent form, leading to the generation of reactive chromium intermediates and oxygen species that can alter normal cellular function and promote apoptosis [86,87]. $\mathrm{Cr}(\mathrm{VI})$ is both mutagenic and carcinogenic to humans [38]. The first report of cancer in workers exposed to chromium is dated to about 130 years ago; after that, $\mathrm{Cr}(\mathrm{VI})$ compounds appeared in the inventory of potential chemical hazards to human health. $\mathrm{Cr}(\mathrm{VI})$ has been classified as a human carcinogen by the International Agency for Research on Cancer [24]. Cr(VI) concentrations in the general population vary depending on the territories and areas considered [88-91]. Rural or suburban air generally contains lower concentrations of chromium than urban air $\left(<10 \mathrm{ng} / \mathrm{m}^{3}\right.$ in rural areas; $0-30 \mathrm{ng} / \mathrm{m}^{3}$ in urban areas). As a result of smoking, indoor air contaminated with $\mathrm{Cr}(\mathrm{VI})$ can be 10-400 times greater than outdoor air concentrations [88]. A plausible route of exposure to $\mathrm{Cr}(\mathrm{VI})$ may be via tap water at concentrations well in excess of the U.S. Environmental Protection Agency (USEPA) maximum contaminant level of $100 \mathrm{microg} / \mathrm{L}$ (ppb) [92]. Recently, Vaiopoulou et al. reported EU legislation with respect to the discharge limits into the aquatic environment for $\mathrm{Cr}(\mathrm{III})$ and $\mathrm{Cr}(\mathrm{VI})$ in comparison to the limits in other parts of the World [93]. In recent years, high concentrations of chromium in various natural systems such as atmosphere, pedosphere, hydrosphere, and biosphere have become a global issue, leading to severe deteriorating effects on different microorganisms, plants, and animals [94]. Chromium is absorbed by plants through carriers of essential ions such as sulfate. Symptoms of chromium toxicity in plants comprise decreased germination, reduction of growth, inhibition of enzymatic activities, impairment of photosynthesis 
and oxidative imbalances [95]. Chromium and its particulates are also released into the oceanic medium in effluent released from ventures like tanneries, materials, mining, coloring, printing, photographic and medicinal industries [96]. Chromium destabilizes the marine ecosystem due to its toxic impact on biota and bioaccumulation in certain organisms. Occurrence of chromium varies in fishes, depending on their age, development as well as other physiological variables. It induces cytotoxicity and detrimental impact on the behavior of fish, such as hypertrophy and paraplegia at gill epithelium, uneven swimming and suspended feeding [97]. Recently, it has been demonstrated that chromate ions may be adsorbed by schwertmannite, a Fe(III)-oxyhydroxysulfate mineral, precipitated over the $\mathrm{pH}$ range of 2.8-4.5 in acid mine drainage and acid rock drainage. Extremely high levels of chromium $(812 \mathrm{mg} / \mathrm{kg}$ ) were enriched in acid mine drainage sediments where schwertmannite formed $[98,99]$. The main mechanisms related to cellular damage caused by $\mathrm{Cr}(\mathrm{VI})$ include high oxidative stress, chromosome breaks, and DNA adduct production. $\mathrm{Cr}(\mathrm{VI})$ is a known irritant and skin sensitizer and can easily penetrate the skin, thus causing inflammation and contact dermatitis [76]. $\mathrm{Cr}(\mathrm{VI})$ is reduced by proteins or intracellular antioxidants to $\mathrm{Cr}(\mathrm{III})$, which, being a hapten, intercalates into DNA or proteins, leading to toxicity as a result. Wang et al. (2010) demonstrated that $\mathrm{Cr}(\mathrm{VI})$ may enhance the generation of ROS inside the cells and stimulate the NF- $\kappa \mathrm{B}$, Akt and MAPK signaling cascades, resulting in higher formation of TNF- $\alpha$ and IL- $1 \alpha$ in keratinocyte in vitro and in a guinea pig in vivo [100]. In 2018, the same authors documented that pterostilbene, a natural compound known for its antioxidant properties, mitigated $\mathrm{Cr}(\mathrm{VI})$ induced skin inflammation by inhibiting TNF- $\alpha$ and NLRP3-inflammasome (IL-1 $\beta$ ) in mice [101]. A serious side effect of chromium intoxication is nephrotoxicity following its elimination via the kidney; high levels of hexavalent chromium are deposited in the kidneys, causing proximal tubule damage [102]. A considerable rise in oxidative stress, nitrosative stress, apoptosis, and inflammation has been demonstrated in the kidney tissue of rats [103]. $\mathrm{Cr}(\mathrm{VI})$ toxicity has been suggested to induce cell apoptosis mostly via intrinsic mitochondrial pathways in human tumour cell lines, anterior pituitary cells, hepatocytic cells and in a rat model. In a recent work, Wu et al. (2020) studied the apoptotic mechanism of $\mathrm{Cr}(\mathrm{VI})$-toxicity in human proximal tubular epithelial HK-2 cell line [104]. They found that both intrinsic and extrinsic apoptotic pathways were activated after exposure to $10 \mu \mathrm{M} \mathrm{Cr}(\mathrm{VI})$. $\mathrm{K}_{2} \mathrm{Cr}_{2} \mathrm{O}_{7}$-induced nephrotoxicity associated with oxidative stress has been shown to be protected by natural antioxidants. Curcumin pretreatment in rats exerts a protective effect by preserving mitochondrial function against $\mathrm{K}_{2} \mathrm{Cr}_{2} \mathrm{O}_{7}$ renal oxidant damage, through direct and indirect antioxidant effects [105]. Barhoma (2018) demonstrated the reno-protective effects of eugenol, a naturally occurring substance, on the injury determined by potassium dichromate intoxication in male rats: it exerted antioxidant activity and also lowered the formation of inflammatory mediators including TNF- [106]. Recently, a multicenter study using human biomonitoring in the assessment of $\mathrm{Cr}(\mathrm{VI})$ exposure and associated health risks in occupational settings has been reported [107]. Epidemiological studies demonstrated that chronic exposure to $\mathrm{Cr}(\mathrm{VI})$ and exposure to high $\mathrm{Cr}(\mathrm{VI})$ concentrations are associated with prostate cancer development and apoptosis induction in nontumorigenic human prostate cells in vitro and in vivo by acting on the epithelial-mesenchymal transition (EMT) pathway $[108,109]$. Low doses of $\mathrm{Cr}(\mathrm{VI})$ may act in two different ways, by downregulating epithelial protein markers, such as E-cadherin, and upregulating mesenchymal protein markers, such as Snail and N-cadherin, as assessed by Zhang et al. [110]. The author suggested inhibition of $\mathrm{Cr}(\mathrm{VI})$-induced EMT signalling as an approach to reduce $\mathrm{Cr}(\mathrm{VI})$-induced prostate tumour progression.

Human oral exposure to $\mathrm{Cr}(\mathrm{VI})$ seems to determine hepatotoxicity since its accumulation takes place mainly in the liver. Mitochondrion is one of the most sensitive targets of $\mathrm{Cr}(\mathrm{VI})$ liver toxicity [111]. Zhong et al. (2017) proposed mitochondrial biogenesis as an adaptive mechanism to counteract $\mathrm{Cr}(\mathrm{VI})$ hepatotoxicity [112]. These authors found that the antioxidant systems and mitochondrial biogenesis were upregulated by low concentrations of $\mathrm{Cr}(\mathrm{VI})$, thus it is conceivable that a compensative mechanism should be generated 
to counteract the $\mathrm{Cr}(\mathrm{VI})$ insult. On the other end, high and cytotoxic concentrations of $\mathrm{Cr}(\mathrm{VI})$ inhibited mitochondrial biogenesis and downregulated the expression of its regulatory factors and antioxidants in HepG2 cells. Thus, pretreatment with $\alpha$-tocopherol was proposed to act against the mitochondrial biogenesis imbalance induced by $\mathrm{Cr}(\mathrm{VI})$.

Recently, Yan et al. (2020) studied the effects of long-term $\mathrm{Cr}(\mathrm{VI})$ exposure on liver toxicity in mice [113]. Results indicated that chronic, low concentration $\mathrm{Cr}$ (VI) treatment induced liver injury characterized by disorganization of liver structure, liver dysfunction, and inhibition of the antioxidant enzyme system. Moreover, the occurrence of liver fibrosis was observed, as a result of hepatic stellate cell triggering mediated by the increased expression levels of Hedgehog signalling network.

$\mathrm{Cr}(\mathrm{VI})$ has been classified as a hazardous air pollutant by the USEPA (2004) [114]. Inhalation of chromium dusts or aerosols has been found to induce respiratory diseases and represents an undoubted risk factor for lung cancer [115]. Salama et al. (2016) studied the effects of chromium in the brain and lungs of rats after intranasal administration of potassium dichromate [114]. Higher concentrations of chromium and elevated levels of oxidative stress and inflammatory markers were observed in brain and lung tissues. This suggested a severe risk of injury in the brain among individuals exposed to chromium dust in low doses, and in brain and lung in the presence of higher chromium concentrations. Han et al. (2019) examined the effects of melatonin on chromium-induced lung injury [116]. They found a protective effect, given that the treatment of rat or mouse lung epithelial cell MLE-12 with melatonin attenuated $\mathrm{K}_{2} \mathrm{Cr}_{2} \mathrm{O}_{7}$-induced lung injury as a result of the reduction of oxidative stress and inflammatory mediator production and inhibition of apoptosis. $\mathrm{Lv}$ et al. (2020) hypothesized that sulforaphane, a naturally occurring isothiocyanate found in cruciferous vegetables, acting as an indirect antioxidant by inducing phase II detoxification enzymes and antioxidant genes, may alleviate lung toxicity in rats chronically exposed to hexavalent chromium [117].

$\mathrm{Cr}(\mathrm{VI})$ has been demonstrated to be an endocrine disruptor: a strong prevalence of premature abortion and infertility was found in women working in chromium industries. The exposure of pregnant rats to $\mathrm{Cr}(\mathrm{VI})$ through drinking water determined the accumulation of chromium in placental tissue. $\mathrm{Cr}(\mathrm{VI})$ seems to break up placenta and enhances cell death by apoptosis [118]. It has been reported that this toxic metal decreases $17 \beta-$ estradiol (E2) biosynthesis and improves metabolic clearance of E2, increasing oxidative stress and decreasing endogenous antioxidants. Resveratrol is able to mitigate the effects of $\mathrm{Cr}(\mathrm{VI})$ by protecting the ovary against its toxicity by enhancing endogenous antioxidant enzymes. It also restored estradiol levels by inhibiting its hydroxylation, glucuronidation and sulphation. Resveratrol was shown to protect the ovary against a $\mathrm{Cr}(\mathrm{VI})$-induced increase in oxidative stress as it lowered lipid peroxidation (LPO) and $\mathrm{H}_{2} \mathrm{O}_{2}$ in plasma and ovary. Furthermore, the protective effects of resveratrol against $\mathrm{Cr}(\mathrm{VI})$-induced decrease in ovarian steroidogenesis have been demonstrated [119].

\section{Chromium Epigenetic Effects on DNA, Histones and MicroRNAs}

Epigenetics refers to hereditary phenotype changes in gene expression without implying changes in the sequence of DNA. Epigenetic regulation of gene expression may be mediated by several mechanisms including DNA hypo- or hypermethylation, the posttranslational modifications of histone tail and small noncoding RNA molecules (microRNA, miRNA), that may interfere with the packaging of DNA around nucleosomes and with gene transcription and translation. DNA methyltransferases, histone methyltransferases, HATs and HDACs are the enzymes implicated in epigenetic mechanisms $[26,120]$. The covalent methylation of DNA in the presence of DNA methyltransferase and SAM (S-adenosyl methionine) takes place through the formation of a bond between a methyl group and cytosine forming 5-methylcytosine (Figure 3A); moreover, 5-methylcytosine can be actively or passively demethylated. The $\mathrm{H} 3$ and $\mathrm{H} 4$ histone tails undergo post-translational reactions that include methylation, acetylation, phosphorylation, ubiquitination and sumoylation. Acetylation (Figure 3B) of the N-terminal lysine residue removes the positive charges 
on the histones abolishing the ionic bonds between the $-\mathrm{NH}_{3}{ }^{+}$terminal groups on the histones with the negative charges of the phosphate groups of DNA. The negative charges, destabilizing the compact DNA-histone structure, lead to a relaxed chromatin structure. Histone acetylation is regulated by enzymatic systems, as histone acetyltransferases (HATs) in the presence of acetyl coenzyme A and the histone deacetylases (HDACs). Histones are also methylated on lysine (Figure 3B), arginine and histidine residues. Unlike acetylation, methylation does not alter the charge of histone. Finally, small noncoding miRNA, formed by 25-30 nucleotides, are involved in the post-transcriptional regulation of protein expression binding to a complementary region on target mRNA and silencing their translation, also reducing expression through induced decapping and deadenylation [121,122]. Small noncoding RNAs are subjected to a covalent methylation modification (6-methyladenosine; 6MeA) (Figure 3C) coordinated by methyltransferases and demethylases. Several authors suggested that $\mathrm{Cr}(\mathrm{VI})$ is able to alter gene expression and induce cancer development through different epigenetic mechanisms. The results of the study of Lou et al. (2013) suggest that $\mathrm{G}_{1}$ phase cell cycle arrest is induced by $\mathrm{Cr}(\mathrm{VI})$ [123]. The exposure to potassium dichromate $\left(\mathrm{K}_{2} \mathrm{Cr}_{2} \mathrm{O}_{7}\right)$ or lead chromate $\left(\mathrm{PbCrO}_{4}\right)$ for 2-24 h can be related to hypomethylation and DNA methylation of p16 gene, which maintained for $20 \mathrm{~h}$. Hu et al. (2016) used in vitro human bronchial epithelial $(16 \mathrm{HBE})$ cells to analyze the epigenetic role of DNA damage following Cr(VI) exposure [124]. CpG1, CpG31 and CpG32 sites of p16 gene were significatively hypermethylated in $\mathrm{Cr}(\mathrm{VI})$ treated groups than controls. Cellular toxicity and p16 expression were demonstrated to be $\mathrm{Cr}(\mathrm{VI})$-concentration dependent. In a following study by the same research group, Hu et al. (2018) examined a cross-sectional study in workers exposed to $\mathrm{Cr}(\mathrm{VI})$ as well as $16 \mathrm{HBE}$ cells treated in vitro with $\mathrm{Cr}(\mathrm{VI})$ [125]. Hypermethylation of CpG sites were observed in both occupationally exposed workers and in 16HBE cells. In addition, in workers a positive relationship existed between blood chromium concentration and methylation of $\mathrm{CPG}$ sites in DNA repair genes: MGMT, HOGG1, and RAD51.

Sun and co-authors (2009) showed that exposing human lung A549 cells to hexavalent chromium increased di-and tri-methylated histone $\mathrm{H} 3$ lysine 9 (H3K9) and H3 lysine 4 (H3K4) levels, while reducing tri-methylated histone H3 lysine 27 (H3K27) and dimethylated histone H3 histidine 2 (H3R2) levels [44]. Furthermore, supplementation of reductant ascorbate, a cofactor necessary for histone demethylase activity, inverted the H3K9 demethylation.

Xia and collaborators [126,127] reported that $\mathrm{Cr}(\mathrm{VI})$ in vitro on human bronchial epithelial cells (HBE16) determined a decrease in H3 and H4 histone acetylation and biotinidase at both protein and mRNA levels; in addition, low doses of $\mathrm{Cr}(\mathrm{VI})(\leq 0.6 \mu \mathrm{M})$ increased histone biotinylation level. Moreover, $\mathrm{Cr}(\mathrm{VI})$-induced deacetylation regulated the histone biotinylation. The study of Chen et al. (2016) [47] demonstrated that Cr(VI) induces a stressor protein Nupr1 (nuclear protein 1), a small protein (molecular weight $8800 \mathrm{Da}$ ), determining the modification of the epigenetic profile with transformation of human bronchial epithelial (BEAS2B) cells. Cr(VI) overexpressed Nupr1 decreased the levels of histone acetyltransferase males absent on the first (MOF) and H4K16 acetylation thus leading to cell transformation [47]. The epigenomic function of vitamin $\mathrm{C}$ plays a pivotal role in improving the activity of Jumonji-C domain-containing histone demethylases (JHDMs) and the ten-eleven translocation (TET) methylcytosine dioxygenases. According to a recent study by Chong et al. (2019) the treatment with high doses of vitamin C should represent nontoxic epigenetic therapy in the treatment of cancer [128]. 

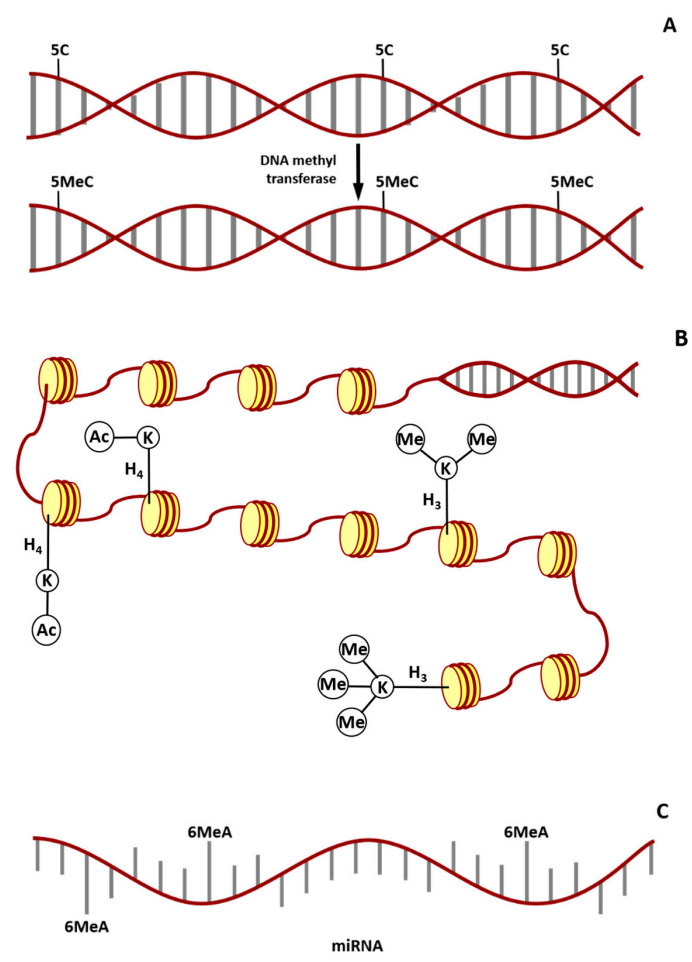

Figure 3. Chromium epigenetic effects on (A) DNA, (B) histones and (C) miRNAs. (A) The methylation of DNA in the presence of DNA methyltransferase involves the bond of a methyl group to the cytosine forming 5-methylcytosine. (B) The H3 and H4 histone tails undergo covalent reactions that include methylation and acetylation. The acetylation of the $N$-terminal lysine residue is a process regulated by histone lysine acetyltransferases. Histones are also methylated on lysine thanks to histone lysine methyltransferases. (C) MicroRNAs are subjected to a covalent methylation modification coordinated by methyltransferases.

The study of $\mathrm{O}^{\prime}$ Hara et al. (2007) revealed that treating BEAS 2B cells with $\mathrm{Cr}(\mathrm{VI})(5 \mu \mathrm{M}$, chosen as a nontoxic exposure) for 4 and $24 \mathrm{~h}$ determined an increase in protein binding to 26 and 43 cis-elements and a decrease in binding to 12 and 26 cis-elements [129]. In addition, $\mathrm{Cr}(\mathrm{VI})$ induces tyrosine phosphorylation and activation of STAT3 (signal transducer and activator of transcription), as well as the endogenous inflammatory gene IL-6. In the study conducted by Chandra and co-authors (2015), Drosophila melanogaster third instar larvae were treated with $\mathrm{Cr}(\mathrm{VI})(5.0-20.0 \mu \mathrm{g} / \mathrm{mL})$ for 24 and $48 \mathrm{~h}$ [130]. MiRNA profile analysis of these larvae showed 28 of 36 differentially expressed miRNAs significantly dysregulated targeting biological processes, such as DNA damage repair, development and differentiation. These results are significant as many Drosophila melanogaster genes have functional homologues in humans.

\section{Chromium Remediation}

Since heavy metals are not degradable, their accumulation in the environment (soil, water and air) may occur, thus contaminating the food chain, engendering a danger to human health. Hexavalent chromium and its oxyanions (e.g., $\mathrm{Cr}_{2} \mathrm{O}_{7}{ }^{2-}, \mathrm{CrO}_{4}{ }^{2-}, \mathrm{HCrO}_{4}{ }^{-}$) are priority targets for the Environmental Protection Agency (EPA) due to their high degree of toxicity. Heavy metal removal is generally carried out by conventional methods involving absorption by ion exchange or chemical resins, that present the limits that they often require co-reagents or exaggerated regeneration chemicals [131] and can undergo slow kinetics with long processing times of the order of hours [132]. Bioremediation may decrease chromium toxicity: some microorganisms are able to secrete chromate reductase that turns highly toxic hexavalent chromium into nontoxic trivalent chromium [133]. Pseudomonas sp. Cr13 can tolerate high concentrations of $\mathrm{Cr}(\mathrm{VI})$ and thus it partially removes $\mathrm{Cr}(\mathrm{VI})[134,135]$. Recently, Acinetobacter sp. Cr1 strain was found to be effective for removal 
of $\mathrm{Cr}$ (VI) [136]. Plants can also be used for phytoremediation by absorbing $\mathrm{Cr}$ from soil into plant organs [137]. Poly(vinyl)ferrocene-carbon nanotube (PVF-CNT) electrodes were used for the removal of anionic chromium from water, with a high adsorption capacity $(>100 \mathrm{mg} / \mathrm{g}$ at saturation) and singular properties of regeneration. Both the release and the regeneration of the electrodes leads to the conversion of the hexavalent pollutant into the less harmful trivalent form [138]. The use of plants to remove nondegradable contaminants from the soil is called phytoextraction and is a green technology used as an awesome alternative to traditional physical and chemical methods that does not impact ecosystems and demands modest economic investment. It has been applied to some heavy metals, such as lead, cadmium and nickel $[139,140]$ and recently mercury and chromium [141,142]. Recently, in a study in the Thi Vai river catchment (Vietnam), mangrove afforestation areas in appropriate locations were suggested to be used for their phytoremediation potential [143]. Novel chitosan-based thin sheet nanofiltration membranes, prepared with chitosan/polyvinyl alcohol/montmorillonite clay, have been recently also proposed for the rejection of chromium [144]. Recently, the use of probiotics was reported to be useful to weaken or hamper the toxic effects of $\mathrm{Cr}(\mathrm{VI})$. In fact, some species of Lactobacillus, Streptococcus, Bacillus and Bifidobacterium present both in the mouth and gut of humans and in fermented foods are able to bind and detoxify some toxic substances, such as $\mathrm{Cr}(\mathrm{VI})$ [145].

\section{Summary}

Chromium belongs to the first series of the transition elements. Comprehension of the biological functions of this element has been considered a subject of discussion for a long time. $\mathrm{Cr}$ (III) is necessary for normal development of humans and animals. It was proposed as an essential trace element over 50 years ago and recently it has been accepted as an essential and pharmacologically active element. It is the most prominent trace mineral involved in the improvement or prevention of hyperglycemia and hyperlipidemia in type 2 diabetes mellitus as it is an important component of glucose tolerance factor. It is present in several foods and supplementation products, including chromium-picolinate, chromium-histidinate, chromium-dinicocysteinate, and niacin-bound chromium. On the other hand, $\mathrm{Cr}(\mathrm{VI})$ is classified by the International Agency for Research on Cancer as a human carcinogen (class I). $\mathrm{Cr}(\mathrm{VI})$-containing compounds are widely recognized as human carcinogens present in industrial settings and in the environment. The reported literature emphasizes that the pharmacokinetic and pharmacodynamic properties of chromium depend on its oxidation state. Although $\mathrm{Cr}(\mathrm{VI})$ is the ion responsible for the toxicity of this metal, molecular damage may be due to its intracellular reduction to the even more highly reactive short-lived chemical species $\mathrm{Cr}(\mathrm{III})$ and $\mathrm{Cr}(\mathrm{V})$. In this paper, both the beneficial and toxic effects of chromium are reviewed. The epigenetic effects of $\mathrm{Cr}(\mathrm{VI})$ on DNA, histones and microRNAs are also addressed, as well as remediation studies. The understanding of the molecular mechanisms responsible for chromium toxicity may lead to finding new therapeutic strategies to cure damage to human health caused by exposure to this metal.

Author Contributions: It is a review. G.G., G.L., A.C. (Alessia Catalano), A.C. (Alessia Carocci) and M.S.S. have read and agreed to the published version of the manuscript.

Funding: This research received no external funding.

Institutional Review Board Statement: Not applicable.

Informed Consent Statement: Not applicable.

Data Availability Statement: Not applicable.

Conflicts of Interest: The authors declare no conflict of interest. 


\section{Abbreviations}

Ac acetyl (Figure 3)

6MeA 6-methyladenosine

$\mathrm{C} \quad$ cytosine (Figure 3)

$5 \mathrm{MeC}$ 5-methylcytosine

K lysine (Figure 3)

AMPK AMP protein kinase

CAFs cancer-associated fibroblasts

COD chemical oxygen demand

CRDC chromium-dinicocysteinate

CrHis chromium-histidinate

CrPic chromium-picolinate

Cys cysteine

E2 17 $\beta$-estradiol

EMT epithelial-mesenchymal transition

EPA Environmental Protection Agency

GLUT4 glucose transporter 4

GTF glucose tolerance factor

$\mathrm{GSH} \quad$ reduced glutathione

H3K9 histone $\mathrm{H} 3$ lysine 9

H3K4 histone $\mathrm{H} 3$ lysine 4

H3K27 histone H3 lysine 27

H3R2 histone $\mathrm{H} 3$ histidine 2

HATs histone acetyltransferase

16HBE human bronchial epithelial

HDACs histone deacetylases

HDL high density lipoprotein

HMG-CoA 3 hydroxy-3-methylglutaryl coenzyme A

HS heat stress

ICAM-1 intercellular adhesion molecule-1

IL-6 interleukin-6

IL-8 interleukin-8

IRI ischemia-reperfusion injury

JHDMs Jumonji-C domain-containing histone demethylases

LDL low density lipoprotein

LDL-c low-density lipoprotein cholesterol

LMWCr low-molecular-weight chromium-binding substance

LPO lipid peroxidation

MAPK mitogen-activated protein kinase

MMTV mouse mammary tumor virus

MOF males absent on the first

mRNA RNA messenger

miRNA microRNA

NBC niacin-bound chromium

$\mathrm{NO}$ nitric oxide

Nupr1 nuclear protein 1

PVF-CNT Poly(vinyl)ferrocene-carbon nanotube

ROS reactive oxygen species

T2DM type 2 diabetes mellitus

TET ten-eleven translocation

TNF- tumor necrosis factor-

USEPA US Environmental Protection Agency

WHO World Health Organization 


\section{References}

1. Vincent, J.B. New evidence against chromium as an essential trace element. J. Nutr. 2017, 147, 2212-2219. [PubMed]

2. Lin, C.C.; Huang, Y.L. Chromium, zinc and magnesium status in type 1 diabetes. Curr. Opin. Clin. Nutr. Metab. Care 2015, 18, 588-592. [CrossRef] [PubMed]

3. Vincent, J.B. Effects of chromium supplementation on body composition, human and animal health, and insulin and glucose metabolism. Curr. Opin. Clin. Nutr. Metab. Care 2019, 22, 483-489. [CrossRef] [PubMed]

4. Baumgard, L.H.; Rhoads, R.P., Jr. Effects of heat stress on postabsorptive metabolism and energetics. Annu. Rev. Anim. Biosci. 2013, 1, 311-337. [CrossRef]

5. Bin-Jumah, M.; El-Hack, A.M.E.; Abdelnour, S.A.; Hendy, Y.A.; Ghanem, H.A.; Alsafy, S.A.; Khafaga, A.F.; Noreldin, A.E.; Shaheen, H.; Samak, D.; et al. Potential use of chromium to combat thermal stress in animals: A review. Sci. Total Environ. 2020, 707, 135996. [CrossRef]

6. Filippini, T.; Cilloni, S.; Malavolti, M.; Violi, F.; Malagoli, C.; Tesauro, M.; Bottecchi, I.; Ferrari, A.; Vescovi, L.; Vinceti, M. Dietary intake of cadmium, chromium, copper, manganese, selenium and zinc in a Northern Italy community. J. Trace Elem. Med. Biol. 2018, 50, 508-517.

7. Anderson, R.A. Chromium as an essential nutrient for humans. Regul. Toxicol. Pharmacol. 1997, 26, S35-S41. [CrossRef]

8. Cefalu, W.T.; Hu, F.B. Role of chromium in human health and in diabetes. Diabetes Care 2004, 27, 2741-2751, Erratum in 2013, 36, 2872. [CrossRef]

9. DesMarias, T.L.; Costa, M. Mechanisms of chromium-induced toxicity. Curr. Opin. Toxicol. 2019, 14, 1-7.

10. Lau, F.C.; Bagchi, M.; Sen, C.K.; Bagchi, D. Nutrigenomic basis of beneficial effects of chromium (III) on obesity and diabetes. Mol. Cell. Biochem. 2008, 317, 1-10. [PubMed]

11. Suksomboon, N.; Poolsup, N.; Yuwanakorn, A. Systematic review and meta-analysis of the efficacy and safety of chromium supplementation in diabetes. J. Clin. Pharm. Ther. 2014, 39, 292-306. [CrossRef] [PubMed]

12. Maret, W. Chromium supplementation in human health, metabolic syndrome, and diabetes. In Essential Metals in Medicine: Therapeutic Use and Toxicity of Metal Ions in the Clinic; De Gruyter: Berlin, Germany, 2019; pp. 231-252.

13. Staniek, H. The combined effects of $\mathrm{Cr}(\mathrm{III})$ propionate complex supplementation and iron excess on copper and zinc status in rats. J. Trace Elem. Med. Biol. 2019, 53, 49-54. [CrossRef] [PubMed]

14. White, P.E.; Vincent, J.B. Systematic review of the effects of chromium (III) on chickens. Biol. Trace Elem. Res. 2019, 188, 99-126. [CrossRef] [PubMed]

15. Hedberg, Y.S. Chromium and leather: A review on the chemistry of relevance for allergic contact dermatitis to chromium. J. Leather Sci. Eng. 2020, 2, 1-15. [CrossRef]

16. Levina, A.; Lay, P.A. Chemical properties and toxicity of chromium (III) nutritional supplements. Chem. Res. Toxicol. 2008, 21, 563-571. [CrossRef] [PubMed]

17. Milačič, R.; Ščančar, J. Cr speciation in foodstuffs, biological and environmental samples: Methodological approaches and analytical challenges-a critical review. TrAC Trends Anal. Chem. 2020, 127, 115888. [CrossRef]

18. Eastmond, D.A.; MacGregor, J.T.; Slesinski, R.S. Trivalent chromium: Assessing the genotoxic risk of an essential trace element and widely used human and animal nutritional supplement. Crit. Rev. Toxicol. 2008, 38, 173-190. [CrossRef]

19. Ferreira, L.M.; Cunha-Oliveira, T.; Sobral, M.C.; Abreu, P.L.; Alpoim, M.C.; Urbano, A.M. Impact of carcinogenic chromium on the cellular response to proteotoxic stress. Int. J. Mol. Sci. 2019, 20, 4901. [CrossRef]

20. Jobby, R.; Jha, P.; Yadav, A.K.; Desai, N. Biosorption and biotransformation of hexavalent chromium [Cr(VI)]: A comprehensive review. Chemosphere 2018, 207, 255-266. [CrossRef]

21. Pellerin, C.; Booker, S.M. Reflections on hexavalent chromium: Health hazards of an industrial heavyweight. Environ. Health Perspect. 2000, 108, A40-A407. [CrossRef]

22. Coetzee, J.J.; Bansal, N.; Chirwa, E.M.N. Chromium in environment, its toxic effect from chromite-mining and ferrochrome industries, and its possible bioremediation. Expo. Health 2020, 12, 51-62. [CrossRef]

23. Tumolo, M.; Ancona, V.; De Paola, D.; Losacco, D.; Campanale, C.; Massarelli, C.; Uricchio, V.F. Chromium Pollution in European Water, Sources, Health Risk, and Remediation Strategies: An Overview. Int. J. Environ. Res. Public Health 2020, 17, 5438. [CrossRef] [PubMed]

24. IARC (International Agency for Research on Cancer). Chromium (VI) Compounds. Monograph 100C; WHO: Geneva, Switzerland, 1990.

25. Chowdhury, S.R.; Yanful, E.K. Arsenic and chromium removal by mixed magnetite-maghemite nanoparticles and the effect of phosphate on removal. J. Environ. Manag. 2010, 91, 2238-2247. [CrossRef] [PubMed]

26. Genchi, G.; Carocci, A.; Lauria, G.; Sinicropi, M.S.; Catalano, A. Nickel: Human health and environmental toxicology. Int. J. Environ. Res. Public Health 2020, 17, 679. [CrossRef]

27. Sepehr, M.N.; Nasseri, S.; Zarrabi, M.; Samarghandi, M.R.; Amrane, A. Removal of Cr(III) from tanning effluent by Aspergillus niger in airlift bioreactor. Sep. Purif. Technol. 2012, 96, 256-262. [CrossRef]

28. Korkmaz, D. Precipitation titration: "determination of chloride by the Mohr method". Methods 2001, 2, 1-6.

29. Li, J.; Luo, G.; He, L.; Xu, J.; Lyu, J. Analytical approaches for determining chemical oxygen demand in water bodies: A review. Crit. Rev. Anal. Chem. 2018, 48, 47-65. [CrossRef] 
30. Guo, W.L.; Chen, M.; Pan, W.L.; Zhang, Q.; Xu, J.X.; Lin, Y.C.; Li, L.; Liu, B.; Bai, W.D.; Zhang, Y.Y.; et al. Hypoglycemic and hypolipidemic mechanism of organic chromium derived from chelation of Grifola frondosa polysaccharide-chromium (III) and its modulation of intestinal microflora in high fat-diet and STZ-induced diabetic mice. Int. J. Biol. Macromol. 2020, 145, 1208-1218. [CrossRef]

31. Pantelić, M.; Jovanović, L.J.; Prodanović, R.; Vujanac, I.; Durić, M.; Culafić, T.; Vranješ-Đurić, S.; Korićanac, G.; Kirovski, D. The impact of the chromium supplementation on insulin signalling pathway in different tissues and milk yield in dairy cows. J. Anim. Physiol. Anim. Nutr. 2018, 102, 41-55.

32. Lewicki, S.; Zdanowski, R.; Krzyzowska, M.; Lewicka, A.; Debski, B.; Niemcewicz, M.; Goniewicz, M. The role of chromium III in the organism and its possible use in diabetes and obesity treatment. Ann. Agric. Environ. Med. 2014, 21, 331-335. [CrossRef]

33. Lapenna, D.; Ciofani, G. Chromium and human low-density lipoprotein oxidation. J. Trace Elem. Med. Biol. 2020, 59, 126411. [CrossRef] [PubMed]

34. Hausladen, D.M.; Fendorf, S. Hexavalent chromium generation within naturally structured soils and sediments. Environ. Sci. Technol. 2017, 51, 2058-2067. [CrossRef] [PubMed]

35. Clodfelder, B.J.; Chang, C.; Vincent, J.B. Absorption of the biomimetic chromium cation triaqua-mu3-oxo-mu-hexapropionatotrich romium(III) in rats. Biol. Trace Elem. Res. 2004, 98, 159-169. [CrossRef]

36. Hininger, I.; Benaraba, R.; Osman, M.; Faure, H.; Roussel, A.M.; Anderson, R.A. Safety of trivalent chromium complexes: No evidence for DNA damage in human HaCaT keratinocytes. Free Rad. Biol. Med. 2007, 42, 1759-1765. [CrossRef]

37. Salnikow, K.; Zhitkovich, A. Genetic and epigenetic mechanisms in metal carcinogenesis and cocarcinogenesis: Nickel, arsenic, and chromium. Chem. Res. Toxicol. 2008, 21, 28-44. [CrossRef] [PubMed]

38. Zhitkovich, A. Importance of chromium-DNA adducts in mutagenicity and toxicity of chromium(VI). Chem. Res. Toxicol. 2005, 18, 3-11. [CrossRef]

39. Qu, Q.; Li, X.; An, F.; Jia, G.; Liu, L.; Watanabe-Meserve, H.; Koenig, K.; Coehn, B.; Costa, M.; Roy, N.; et al. CrVI exposure and biomarkers: $\mathrm{Cr}$ in erythrocytes in relation to exposure and polymorphisms of genes encoding anion transport proteins. Biomarkers 2008, 13, 467-477. [CrossRef] [PubMed]

40. De Flora, S. Threshold mechanisms and site specificity in chromium(VI) carcinogenesis. Carcinogenesis 2000, $21,533-541$. [CrossRef]

41. Zhitkovich, A. Chromium in drinking water: Sources, metabolism, and cancer risks. Chem. Res. Toxicol. 2011, 24, 1617-1629. [CrossRef]

42. Sun, H.; Brocato, J.; Costa, M. Oral chromium exposure and toxicity. Curr. Environ. Health Rep. 2015, 2, 295-303. [CrossRef]

43. Pavesi, T.; Moreira, J.C. Mechanisms and individuality in chromium toxicity in humans. J. Appl. Toxicol. 2020, 40, 1183-1197. [CrossRef] [PubMed]

44. Sun, H.; Zhou, X.; Chen, H.; Li, Q.; Costa, M. Modulation of histone methylation and MLH1 gene silencing by hexavalent chromium. Toxicol. Appl. Pharmacol. 2009, 237, 258-266. [PubMed]

45. Arita, A.; Shamy, M.Y.; Chervona, Y.; Clancy, H.A.; Sun, H.; Hall, M.N.; Qu, Q.; Gamble, M.-V.; Costa, M. The effect of exposure to carcinogenic metals on histone tail modifications and gene expression in human subjects. J. Trace Elem. Med. Biol. 2012, 26, 174-178. [CrossRef] [PubMed]

46. Chervona, Y.; Costa, M. The control of histone methylation and gene expression by oxidative stress, hypoxia, and metals. Free Radic. Biol. Med. 2012, 53, 1041-1047. [CrossRef]

47. Chen, D.; Kluz, T.; Fang, L.; Zhang, X.; Sun, H.; Jin, C.; Costa, M. Hexavalent chromium (Cr(VI)) down-regulates acetylation of histone H4 at lysine 16 through induction of stressor protein Nupr1. PLoS ONE 2016, 11, e0157317. [CrossRef]

48. Kumpulainen, J.T. Chromium content of foods and diets. Biol. Trace Elem. Res. 1992, 32, 9-18. [CrossRef]

49. Roussel, A.-M.; Andriollo-Sanchez, M.; Ferry, M.; Bryden, N.A.; Anderson, R.A. Food chromium content, dietary chromium intake and related biological variables in French free-living elderly. Br. J. Nutr. 2007, 98, 326-331. [CrossRef]

50. Institute of Medicine. Dietary Reference Intakes for Vitamin A, Vitamin K, Arsenic, Boron, Chromium, Copper, Iodine, Iron, Manganese, Molybdenum, Nickel, Silicon, Vanadium, and Zinc: A Report of the Panel on Micronutrients; National Academy Press: Washington, DC, USA, 2001.

51. EFSA Panel on Food Additives and Nutrient Sources added to Food (ANS). Scientific Opinion on the safety of trivalent chromium as a nutrient added for nutritional purposes to foodstuffs for particular nutritional uses and foods intended for the general population (including food supplements). EFSA J. 2010, 8, 1882.

52. Moffat, I.; Martinova, N.; Seidel, C.; Thompson, C.M. Hexavalent chromium in drinking water. J. Am. Water Work. Assoc. 2018, 110, E22-E35. [CrossRef]

53. Genchi, G.; Sinicropi, M.S.; Lauria, G.; Carocci, A.; Catalano, A. The Effects of Cadmium Toxicity. Int. J. Environ. Res. Public Health 2020, 17, 3782. [CrossRef]

54. EC (European Commission). Opinion of the Scientific Committee on Food on the Tolerable Upper Intake Level of Trivalent Chromium, expressed in 4 April 2003. Available online: http:/ / ec.europa.eu/food/fs/sc/scf/out197_en.pdf (accessed on 29 April 2010).

55. Laschinsky, N.; Kottwitz, K.; Freund, B.; Dresow, B.; Fischer, R.; Nielsen, P. Bioavailability of chromium (III)-supplements in rats and humans. Biometals 2012, 25, 1051-1060. [CrossRef] [PubMed] 
56. Zha, L.Y.; Xu, Z.R.; Wang, M.Q.; Gu, L.Y. Effects of chromium nanoparticle dosage on growth, body composition, serum hormones and tissue chromium in Sprague-Dawley rats. J. Zhejiang Univ. Sci. B 2007, 8, 323-330. [CrossRef] [PubMed]

57. Samanta, S.; Haldar, S.; Ghosh, T.K. Production and carcase traits in broiler chickens given diets supplemented with inorganic trivalent chromium and an organic acid blend. Br. Poult. Sci. 2008, 49, 155-163. [CrossRef] [PubMed]

58. Lukaski, H.C. Effects of chromium (III) as a nutritional supplement. In The Nutritional Biochemistry of Chromium (III); Elsevier: Amsterdam, The Netherlands, 2019; pp. 31-77.

59. Vincent, J.B.; Lukaski, H.C. Chromium. Adv. Nutr. 2018, 9, 505-506. [CrossRef]

60. Clodfelder, B.J.; Emamaullee, J.; Hepburn, D.D.; Chakov, N.E.; Nettles, H.S.; Vincent, J.B. The trail of chromium(III) in vivo from the blood to the urine: The roles of transferrin and chromodulin. J. Biol. Inorg. Chem. 2001, 6, 608-617. [CrossRef]

61. Carocci, A.; Catalano, A.; Sinicropi, M.S.; Genchi, G. Oxidative stress and neurodegeneration: The involvement of iron. Biometals 2018, 31, 715-735. [CrossRef]

62. Edwards, K.C.; Kim, H.; Vincent, J.B. Release of trivalent chromium from serum transferrin is sufficiently rapid to be physiologically relevant. J. Inorg. Biochem. 2020, 202, 110901. [CrossRef]

63. Bjørklund, G.; Aaseth, J.; Skalny, A.V.; Suliburska, J.; Skalnaya, M.G.; Nikonorov, A.A.; Tinkov, A.A. Interactions of iron with manganese, zinc, chromium, and selenium as related to prophylaxis and treatment of iron deficiency. J. Trace Elem. Med. Biol. 2017, 41, 41-53. [CrossRef]

64. Clodfelder, B.J.; Vincent, J.B. The time-dependent transport of chromium in adult rats from the bloodstream to the urine. J. Biol. Inorg. Chem. 2005, 10, 383-393. [CrossRef]

65. Kirman, C.R.; Suh, M.; Proctor, D.M.; Hays, S.M. Improved physiologically based pharmacokinetic model for oral exposures to chromium in mice, rats, and humans to address temporal variation and sensitive populations. Toxicol. Appl. Pharmacol. 2017, 325, 9-17. [CrossRef]

66. Baj, J.; Flieger, W.; Teresiński, G.; Buszewicz, G.; Sitarz, E.; Forma, A.; Karakuła, K.; Maciejewski, R. Magnesium, calcium, potassium, sodium, phosphorus, selenium, zinc, and chromium levels in alcohol use disorder: A review. J. Clin. Med. 2020, 9, 1901. [CrossRef] [PubMed]

67. Schwarz, K.; Mertz, W. Chromium(III) and the glucose tolerance factor. Arch. Biochem. Biophys. 1959, 85, 292-295. [CrossRef]

68. World Health Organization (WHO). Trace Elements in Human Nutrition and Health; World Health Organization: Geneva, Switzerland, 1996.

69. Lai, M.H.; Chen, Y.Y.; Cheng, H.H. Chromium yeast supplementation improves fasting plasma glucose and LDL-cholesterol in streptozotocin-induced diabetic rats. Int. J. Vitam. Nutr. Res. 2006, 76, 391-397. [CrossRef] [PubMed]

70. Schrauzer, G.N. Interactive effects of selenium and chromium on mammary tumor development and growth in MMTV-infected female mice and their relevance to human cancer. Biol. Trace Elem. Res. 2006, 109, 281-292. [CrossRef]

71. Vincent, J.B. Is the pharmacological mode of action of chromium(III) as a second messenger? Biol. Trace Elem. Res. 2015, 166, 7-12. [CrossRef]

72. Chen, G.; Liu, P.; Pattar, G.R.; Tackett, L.; Bhonagiri, P.; Strawbridge, A.B.; Elmendorf, J.S. Chromium activates glucose transporter 4 trafficking and enhances insulin-stimulated glucose transport in 3T3-L1 adipocytes via a cholesterol-dependent mechanism. Mol. Endocrinol. 2006, 20, 857-870. [CrossRef]

73. Pattar, G.R.; Tackett, L.; Liu, P.; Elmendorf, J.S. Chromium picolinate positively influences the glucose transporter system via affecting cholesterol homeostasis in adipocytes cultured under hyperglycemic diabetic conditions. Mutat. Res. 2006, 610, 93-100. [CrossRef]

74. Raja, N.S.; Sankaranarayanan, K.; Dhathathreyan, A.; Nair, B.U. Interaction of chromium(III) complexes with model lipid bilayers: Implications on cellular uptake. Biochim. Biophys. Acta 2011, 1808, 332-340. [CrossRef]

75. Adam, C.; Wohlfarth, J.; Haussmann, M.; Sennefelder, H.; Rodin, A.; Maler, M.; Martin, S.F.; Goebeler, M.; Schmidt, M. Allergyinducing chromium compounds trigger potent innate immune stimulation via ROS-dependent inflammasome activation. $J$. Investig. Dermatol. 2017, 137, 367-376. [CrossRef]

76. Bregnbak, D.; Johansen, J.D.; Jellesen, M.S.; Zachariae, C.; Menné, T.; Thyssen, J.P. Chromium allergy and dermatitis: Prevalence and main findings. Contact Dermat. 2015, 73, 261-280. [CrossRef]

77. Qin, J.; Li, Y.; Cai, Z.; Li, S.; Zhu, J.; Zhang, F.; Liang, S.; Zhang, W.; Guan, Y.; Shen, D.; et al. A metagenome-wide association study of gut microbiota in type 2 diabetes. Nature 2012, 490, 55-60. [CrossRef]

78. Wang, J.; Jia, H. Metagenome-wide association studies: Fine-mining the microbiome. Nat. Rev. Microbiol. 2016, 14, 508-522. [CrossRef] [PubMed]

79. Kashyap, S.R.; Defronzo, R.A. The insulin resistance syndrome: Physiological considerations. Diab. Vasc. Dis. Res. 2007, 4, 13-19. [CrossRef] [PubMed]

80. San Mauro, I.; Ruiz-Leon, A.M.; Camina Martin, M.A.; Garicano-Vilar, E.; Collado-Yurrita, L.; de Mateo-Silleras, B.; del Río, P.R. Chromium supplementation in patients with type 2 diabetes and high risk of type 2 diabetes: A meta-analysis of randomized controlled trials. Nutr. Hosp. 2016, 33, 156-161. [CrossRef]

81. Penumathsa, S.V.; Thirunavukkarasu, M.; Samuel, M.; Zhan, L.; Maulik, G.; Bagchi, M.; Bagchi, D.; Maulik, N. Niacin bound chromium treatment induces myocardial Glut-4 translocation and caveolar interaction via Akt, AMPK and eNOS phosphorylation in streptozotocin induced diabetic rats after ischemia-reperfusion injury. Biochim. Biophys. Acta 2009, 1792, 39-48. [CrossRef] [PubMed] 
82. Jain, S.K.; Kahlon, G.; Moorehead, L.; Dhawan, R.; Lieblong, B.; Stapleton, T.; Caldito, G.; Hoeldtke, R.; Levine, S.N.; Farrington Bass, P. Effect of chromium dinicocysteinate supplementation on circulating levels of insulin, TNF- $\alpha$, oxidative stress and insulin resistance in type 2 diabetic patients: Randomized, double-blind, placebo-controlled study. Mol. Nutr. Food Res. 2012, 56, 1333-1341. [CrossRef] [PubMed]

83. Saiyed, Z.M.; Lugo, J.P. Impact of chromium dinicocysteinate supplementation on inflammation, oxidative stress, and insulin resistance in type 2 diabetic subjects: An exploratory analysis of a randomized, double-blind, placebo-controlled study. Food Nutr. Res. 2016, 60, 31762. [CrossRef] [PubMed]

84. Abebe, W.; Liu, J.Y.; Wimborne, H.; Mozaffari, M.S. Effects of chromium picolinate on vascular reactivity and cardiac ischemiareperfusion injury in spontaneously hypertensive rats. Pharmacol. Rep. 2010, 62, 674-682. [CrossRef]

85. Grande, F.; Parisi, O.I.; Mordocco, R.A.; Rocca, C.; Puoci, F.; Scrivano, L.; Quintieri, A.M.; Cantafio, P.; Ferla, S.; Brancale, A.; et al. Quercetin derivatives as novel antihypertensive agents: Synthesis and physiological characterization. Eur. J. Pharm. Sci. 2016, 82, 161-170. [CrossRef]

86. Hu, G.; Zheng, P.; Feng, H.; Jia, G. Imbalance of oxidative and reductive species involved in chromium(VI)-induced toxic effects. React. Oxyg. Species 2017, 3,1-11.

87. Rizza, P.; Pellegrino, M.; Caruso, A.; Iacopetta, D.; Sinicropi, M.S.; Rault, S.; Lancelot, J.C.; El-Kashef, H.; Lesnard, A.; Rochais, C.; et al. 3-(Dipropylamino)-5-hydroxybenzofuro[2,3-f]quinazolin-1(2H)-one (DPA-HBFQ-1) plays an inhibitory role on breast cancer cell growth and progression. Eur. J. Med. Chem. 2016, 107, 275-287. [CrossRef] [PubMed]

88. Wilbur, S.; Abadin, H.; Fay, M.; Yu, D.; Tencza, B.; Ingerman, L.; Klotzbach, J.; James, S. Toxicological Profile for Chromium; Agency for Toxic Substances and Disease Registry (ATSDR) Toxicological Profiles: Atlanta, GA, USA, 2012.

89. Rowbotham, A.L.; Levy, L.S.; Shuker, L.K. Chromium in the Environment: An Evaluation of Exposure of the UK General Population and Possible Adverse Health Effects. J. Toxicol. Environ. Health 2000, 3, 145-178.

90. Meaza, I.; Speer, R.M.; Toyoda, J.H.; Lu, H.; Wise, S.S.; Croom-Perez, T.J.; Aboueissa, A.E.; Wise Sr, J.P. Prolonged exposure to particulate $\mathrm{Cr}$ (VI) is cytotoxic and genotoxic to fin whale cells. J. Trace Elem. Med. Biol. 2020, 126562. [CrossRef]

91. Xu, J.; Zhao, M.; Pei, L.; Zhang, R.; Liu, X.; Wei, L.; Yang, M.; Xu, Q. Oxidative stress and DNA damage in a long-term hexavalent chromium exposed population in North China: A cross-sectional study. BMJ Open 2018, 8, 021470. [CrossRef] [PubMed]

92. Paustenbach, D.; Finley, B.; Mowat, F.; Kerger, B. Human health risk and exposure assessment of chromium (VI) in tap water. J. Toxicol. Environ. Health Part A 2003, 66, 1295-1339. [CrossRef] [PubMed]

93. Vaiopoulou, E.; Gikas, P. Regulations for chromium emissions to the aquatic environment in Europe and elsewhere. Chemosphere 2020, 254, 126876. [CrossRef]

94. Rahman, Z.; Singh, V.P. The relative impact of toxic heavy metals (THMs) (arsenic (As), cadmium (Cd), chromium (Cr)(VI), mercury $(\mathrm{Hg})$, and lead $(\mathrm{Pb}))$ on the total environment: An overview. Environ. Monit. Assess. 2019, 191, 419. [CrossRef]

95. Ertani, A.; Mietto, A.; Borin, M.; Nardi, S. Chromium in agricultural soils and crops: A review. Water Air Soil Pollut. 2017, 228, 190. [CrossRef]

96. GracePavithra, K.; Jaikumar, V.; Kumar, P.S.; SundarRajan, P. A review on cleaner strategies for chromium industrial wastewater: Present research and future perspective. J. Clean. Prod. 2019, 228, 580-593. [CrossRef]

97. Aslam, S.; Yousafzai, A.M. Chromium toxicity in fish: A review article. J. Entomol. Zool. Stud. 2017, 5, $1483-1488$.

98. Chen, M.; Lu, G.; Wu, J.; Yang, C.; Niu, X.; Tao, X.; Shi, Z.; Yi, X.; Dang, Z. Migration and fate of metallic elements in a waste mud impoundment and affected river downstream: A case study in Dabaoshan Mine, South China. Ecotoxicol. Environ. Saf. 2018, 164, 474-483. [CrossRef] [PubMed]

99. Fan, C.; Guo, C.; Zeng, Y.; Tu, Z.; Ji, Y.; Reinfelder, J.R.; Chen, M.; Huang, W.; Lu, G.; Yi, X.; et al. The behavior of chromium and arsenic associated with redox transformation of schwertmannite in AMD environment. Chemosphere 2019, 222, 945-953. [CrossRef]

100. Wang, B.J.; Sheu, H.M.; Guo, Y.L.; Lee, Y.H.; Lai, C.S.; Pan, M.H.; Wang, Y.J. Hexavalent chromium induced ROS formation, Akt, NF-kappaB, and MAPK activation, and TNF-alpha and IL-1alpha production in keratinocytes. Toxicol. Lett. 2010, 198, 216-224. [CrossRef] [PubMed]

101. Wang, B., Jr.; Chiu, H.W.; Lee, Y.L.; Li, C.Y.; Wang, Y.J.; Lee, Y.H. Pterostilbene attenuates hexavalent chromium-induced allergic contact dermatitis by preventing cell apoptosis and inhibiting IL-1 $\beta$-related NLRP3 inflammasome activation. J. Clin. Med. 2018, 7, 489. [CrossRef]

102. Hegazy, R.; Salama, A.; Mansour, D.; Hassan, A. Renoprotective effect of lactoferrin against chromium-induced acute kidney injury in rats: Involvement of IL-18 and IGF-1 inhibition. PLoS ONE 2016, 11, e0151486. [CrossRef]

103. Sahu, B.D.; Koneru, M.; Bijargi, S.R.; Kota, A.; Sistla, R. Chromium-induced nephrotoxicity and ameliorative effect of carvedilol in rats: Involvement of oxidative stress, apoptosis and inflammation. Chem. Biol. Interact. 2014, 223, 69-79. [CrossRef]

104. Wu, Y.H.; Lin, J.C.; Wang, T.Y.; Lin, T.J.; Yen, M.C.; Liu, Y.H.; Wu, P.L.; Chen, F.W.; Shih, Y.L.; Yeh, I.J. Hexavalent chromium intoxication induces intrinsic and extrinsic apoptosis in human renal cells. Mol. Med. Rep. 2020, 21, 851-857. [CrossRef]

105. Molina-Jijón, E.; Tapia, E.; Zazueta, C.; El Hafidi, M.; Zatarain-Barrón, Z.L.; Hernández-Pando, R.; Pedraza-Chaverri, J. Curcumin prevents Cr(VI)-induced renal oxidant damage by a mitochondrial pathway. Free Radic. Biol. Med. 2011, 51, 1543-1557. [CrossRef]

106. Barhoma, R.A. The role of eugenol in the prevention of chromium-induced acute kidney injury in male albino rats. Alexandria $J$. Med. 2018, 54, 711-715. [CrossRef] 
107. Santonen, T.; Alimonti, A.; Bocca, B.; Duca, R.C.; Galea, K.S.; Godderis, L.; Göen, T.; Gomes, B.C.; Hanser, O.; Iavicoli, I.; et al. Setting up a collaborative European human biological monitoring study on occupational exposure to hexavalent chromium. Environ. Res. 2019, 177, 108583. [CrossRef]

108. Núñez, O.; Fernández-Navarro, P.; Martín-Méndez, I.; Bel-Lan, A.; Locutura, J.F.; López-Abente, G. Arsenic and chromium topsoil levels and cancer mortality in Spain. Environ. Sci. Pollut. Res. Int. 2016, 23, 17664-17675. [CrossRef] [PubMed]

109. El-Atta, H.M.A.; El-Bakary, A.A.; Attia, A.M.; Lotfy, A.; Khater, S.S.; Elsamanoudy, A.Z.; Abdalla, H.A. DNA fragmentation, caspase 3 and prostate-specific antigen genes expression induced by arsenic, cadmium, and chromium on nontumorigenic human prostate cells. Biol. Trace Elem. Res. 2014, 162, 95-105. [CrossRef] [PubMed]

110. Zhang, C.; Cai, K.; Feng, Q.; Xu, Y.; Zhang, Z. Chromium (VI) promotes cell migration through targeting epithelial-mesenchymal transition in prostate cancer. Toxicol. Lett. 2019, 300, 10-17. [CrossRef] [PubMed]

111. Xiao, F.; Li, Y.; Luo, L.; Xie, Y.; Zeng, M.; Wang, A.; Chen, H.; Zhong, C. Role of mitochondrial electron transport chain dysfunction in $\mathrm{Cr}(\mathrm{VI})$-induced cytotoxicity in L-02 hepatocytes. Cell. Physiol. Biochem. 2014, 33, 1013-1025.

112. Zhong, X.; Zhong, C. Mitochondrial biogenesis in response to chromium(VI) toxicity in human liver cells. Int. J. Mol. Sci. 2017, 18, 1877. [CrossRef]

113. Yan, J.; Huang, H.; Liu, Z.; Shen, J.; Ni, J.; Han, J.; Wang, R.; Lin, D.; Hu, B.; Jin, L. Hedgehog signaling pathway regulates hexavalent chromium-induced liver fibrosis by activation of hepatic stellate cells. Toxicol. Lett. 2020, 320, 1-8. [CrossRef]

114. Salama, A.; Hegazy, R.; Hassan, A. Intranasal chromium induces acute brain and lung injuries in rats: Assessment of different potential hazardous effects of environmental and occupational exposure to chromium and introduction of a novel pharmacological and toxicological animal model. PLoS ONE 2016, 11, e0168688.

115. Urbano, A.M.; Ferreira, L.M.; Alpoim, M.C. Molecular and cellular mechanisms of hexavalent chromium-induced lung cancer: An updated perspective. Curr. Drug Metab. 2012, 13, 284-305. [CrossRef]

116. Han, B.; Li, S.; Lv, Y.; Yang, D.; Li, J.; Yang, Q.; Wu, P.; Lv, Z.; Zhang, Z. Dietary melatonin attenuates chromium-induced lung injury via activating the Sirt1/Pgc-1 $\alpha / \mathrm{Nrf2}$ pathway. Food Funct. 2019, 10, 5555-5565. [CrossRef]

117. Lv, Y.; Jiang, H.; Li, S.; Han, B.; Liu, Y.; Yang, D.; Zhang, Z. Sulforaphane prevents chromium-induced lung injury in rats via activation of the Akt/GSK-3 $\beta$ /Fyn pathway. Environ. Pollut. 2020, 259, 113812. [CrossRef]

118. Banu, S.K.; Stanley, J.A.; Sivakumar, K.K.; Arosh, J.A.; Taylor, R.J.; Burghardt, R.C. Chromium VI-Induced developmental toxicity of placenta is mediated through spatiotemporal dysregulation of cell survival and apoptotic proteins. Reprod. Toxicol. 2017, 68, 171-190. [CrossRef]

119. Banu, S.K.; Stanley, J.A.; Sivakumar, K.K.; Arosh, J.A.; Burghardt, R.C. Resveratrol protects the ovary against chromium-toxicity by enhancing endogenous antioxidant enzymes and inhibiting metabolic clearance of estradiol. Toxicol. Appl. Pharmacol. 2016, 303, 65-78. [CrossRef]

120. Koturbash, I.; Beland, F.A.; Pogribny, I.P. Role of epigenetic events in chemical carcinogenesis-a justification for incorporating epigenetic evaluations in cancer risk assessment. Toxicol. Mech. Methods 2011, 21, 289-297. [CrossRef] [PubMed]

121. Pillai, R.S.; Bhattacharyya, S.N.; Filipowicz, W. Repression of protein synthesis by miRNAs: How many mechanisms? Trends Cell. Biol. 2007, 17, 118-126. [CrossRef] [PubMed]

122. Mott, J.L.; Mohr, A.M. Overview of microRNA biology. Semin. Liver Dis. 2015, 35, 3-11.

123. Lou, J.; Wang, Y.; Yao, C.; Jin, L.; Wang, X.; Xiao, Y.; Wu, N.; Song, P.; Song, Y.; Tan, Y.; et al. Role of DNA methylation in cell cycle arrest induced by $\mathrm{Cr}(\mathrm{VI})$ in two cell lines. PLoS ONE 2013, 8, e71031. [CrossRef] [PubMed]

124. Hu, G.; Li, P.; Li, Y.; Wang, T.; Gao, X.; Zhang, W.; Jia, G. Methylation levels of P16 and TP53 that are involved in DNA strand breakage of $16 \mathrm{HBE}$ cells treated by hexavalent chromium. Toxicol. Lett. 2016, 249, 15-21. [CrossRef]

125. Hu, G.; Li, P.; Cui, X.; Li, Y.; Zhang, J.; Zhai, X.; Yu, S.; Tang, S.; Zhao, Z.; Wang, J.; et al. Cr(VI)-induced methylation and down-regulation of DNA repair genes and its association with markers of genetic damage in workers and 16HBE cells. Environ. Pollut. 2018, 238, 833-843. [CrossRef] [PubMed]

126. Xia, B.; Yang, L.; Huang, H.; Pang, L.; Hu, G.; Liu, Q.; Yuan, J.; Liu, J.; Xia, Y.; Zhuang, Z. Chromium(VI) causes down regulation of biotinidase in human bronchial epithelial cells by modifications of histone acetylation. Toxicol. Lett. 2011, 205, 140-145. [CrossRef]

127. Xia, B.; Ren, X.; Zhuang, Z.; Yang, L.; Huang, H.; Pang, L.; Wu, D.; Luo, J.; Tan, Y.; Liu, J.; et al. Effect of hexavalent chromium on histone biotinylation in human bronchial epithelial cells. Toxicol. Lett. 2014, 228, 241-247. [CrossRef]

128. Chong, T.L.; Ahearn, E.L.; Cimmino, L. Reprogramming the epigenome with vitamin C. Front. Cell Dev. Biol. $2019,7,128$. [CrossRef] [PubMed]

129. O’Hara, K.A.; Vaghjiani, R.J.; Nemec, A.A.; Klei, L.R.; Barchowsky, A. Cr(VI)-stimulated STAT3 tyrosine phosphorylation and nuclear translocation in human airway epithelial cells requires Lck. Biochem. J. 2007, 402, 261-269. [CrossRef] [PubMed]

130. Chandra, S.; Pandey, A.; Chowdhuri, D.K. MiRNA profiling provides insights on adverse effects of Cr(VI) in the midgut tissues of Drosophila melanogaster. J. Hazard. Mater. 2015, 283, 558-567. [CrossRef] [PubMed]

131. Huang, G.L.; Zhang, H.Y.; Shi, J.X.; Langrish, T.A.G. Adsorption of chromium(VI) from aqueous solutions using cross-linked magnetic chitosan beads. Ind. Eng. Chem. Res. 2009, 48, 2646-2651. [CrossRef]

132. Santhosh, C.; Daneshvar, E.; Kollu, P.; Peraniemi, S.; Grace, A.N.; Bhatnagar, A. Magnetic $\mathrm{SiO}_{2}-\mathrm{CoFe}_{2} \mathrm{O}_{4}$ nanoparticles decorated on graphene oxide as efficient adsorbents for the removal of anionic pollutants from water. Chem. Eng. J. 2017, 322, 472-487. [CrossRef] 
133. Bhattacharya, A.; Gupta, A.; Kaur, A.; Malik, D. Alleviation of hexavalent chromium by using microorganisms: Insight into the strategies and complications. Water Sci. Technol. 2019, 79, 411-424. [CrossRef]

134. Singh, V.; Chauhan, P.K.; Kanta, R.; Dhewa, T.; Kumar, V. Isolation and characterization of Pseudomonas resistant to heavy metals contaminants. Int. J. Pharm. Sci. Rev. Res. 2010, 3, 164-167.

135. Gong, D.; Ye, F.; Pang, C.; Lu, Z.; Shang, C. Isolation and Characterization of Pseudomonas sp. Cr13 and Its Application in Removal of Heavy Metal Chromium. Curr. Microbiol. 2020, 77, 3661-3670. [CrossRef]

136. Pang, B.; Lv, L.; Pang, C.; Ye, F.; Shang, C. Optimization of Growth Conditions of Acinetobacter sp. Cr1 for Removal of Heavy Metal Cr Using Central Composite Design. Curr. Microbiol. 2020. [CrossRef]

137. Guo, S.; Xiao, C.; Zhou, N.; Chi, R. Speciation, toxicity, microbial remediation and phytoremediation of soil chromium contamination. Environ. Chem. Lett. 2020, 1-19. [CrossRef]

138. Su, X.; Kushima, A.; Halliday, C.; Zhou, J.; Li, J.; Hatton, T.A. Electrochemically-mediated selective capture of heavy metal chromium and arsenic oxyanions from water. Nat. Commun. 2018, 9, 1-9.

139. Petrella, A.; Spasiano, D.; Acquafredda, P.; De Vietro, N.; Ranieri, E.; Cosma, P.; Petruzzelli, D. Heavy metals retention (Pb (II), Cd (II), Ni (II)) from single and multimetal solutions by natural biosorbents from the olive oil milling operations. Process Saf. Environ. Prot. 2018, 114, 79-90. [CrossRef]

140. Carocci, A.; Catalano, A.; Lauria, G.; Sinicropi, M.S.; Genchi, G. Lead toxicity, antioxidant defense and environment. In Reviews of Environmental Contamination and Toxicology; Springer: Cham, Switzerland, 2016; pp. 45-67.

141. Ranieri, E.; Moustakas, K.; Barbafieri, M.; Ranieri, A.C.; Herrera-Melián, J.A.; Petrella, A.; Tommasi, F. Phytoextraction technologies for mercury-and chromium-contaminated soil: A review. J. Chem. Technol. Biotechnol. 2020, 95, 317-327. [CrossRef]

142. Genchi, G.; Sinicropi, M.S.; Carocci, A.; Lauria, G.; Catalano, A. Mercury exposure and heart diseases. Int. J. Environ. Res. Public Health 2017, 14, 74. [CrossRef]

143. Nguyen, A.; Le, B.V.; Richter, O. The Role of Mangroves in the Retention of Heavy Metal (Chromium): A Simulation Study in the Thi Vai River Catchment, Vietnam. Int. J. Environ. Res. Public Health 2020, 17, 5823. [CrossRef] [PubMed]

144. Sangeetha, K.; Sudha, P.N.; Sukumaran, A. Novel chitosan based thin sheet nanofiltration membrane for rejection of heavy metal chromium. Int. J. Biol. Macromol. 2019, 132, 939-953.

145. Younan, S.; Sakita, G.Z.; Albuquerque, T.R.; Keller, R.; Bremer-Neto, H. Chromium (VI) bioremediation by probiotics. J. Sci. Food Agric. 2016, 96, 3977-3982. [CrossRef] 